\title{
LOS CONSERVADORES CONTRAATACAN. \\ REPENSANDO LA POLÍTICA PRESIDENCIAL Y LAS REDES POLÍTICO-PARTIDARIAS EN TIEMPos de Ramón S. Castillo (Argentina, 1940-1943)
}

\begin{abstract}
RESUMEN
Este artículo analiza la política presidencial en tiempos de Ramón Castillo a través de una reconsideración de sus capacidades políticas y recursos partidarios. Lo hace a través de una reevaluación de los intentos del último Presidente conservador argentino por reconstruir el tejido político-partidario en algunos casos provinciales como Jujuy, Corrientes y Tucumán. A través de un variado repertorio de fuentes como prensa, correspondencia privada y documentos oficiales, el artículo concluye que, si bien las habilidades políticas y los recursos del Presidente no fueron suficientes para garantizar su supervivencia en el poder, parte de la explicación a su caída debe buscarse en la misma política que promovió el Poder Ejecutivo, sus unilaterales acciones y sus inesperadas consecuencias.
\end{abstract}

Palabras claves: Argentina, siglo xx, Ramón S. Castillo, liderazgo presidencial, partidos políticos, conservadurismo.

\begin{abstract}
This article analyzes presidential policy during the times of Ramón Castillo through a reconsideration of his political capacities and party resources. It is carried out mainly through a reevaluation of the attempts made by the last conservative Argentinean president to reconstruct the political-party fabric concerning some provincial cases like Jujuy, Corrientes and Tucumán. Through a varied repertoire of sources like the press, private correspondence and official documents, the article concludes that, if the political abilities and the resources of the president were not sufficient to guarantee his survival in power, a partial explanation of his fall should be found in the same policy that promoted the Executive Power, his unilateral actions, and their unexpected consequences.
\end{abstract}

Keywords: Argentina, twentieth-century, Ramón S. Castillo, presidential leadership, political parties, conservatism.

Recibido: Abril 2017.

Aceptado: Agosto 2017.

\footnotetext{
* Doctor en Historia por la Universidad Torcuato Di Tella (Argentina). Becario posdoctoral del Consejo Nacional de Investigaciones Científicas y Técnicas (CONICET) en el Instituto de Investigaciones de la Facultad de Ciencias Sociales de la Pontificia Universidad Católica Argentina. Correo electrónico: ignacioalopez@uca.edu.ar
} 


\section{INTRODUCCIÓN $^{1}$}

Las interpretaciones que la historiografía brindó sobre el proceso republicano argentino encerrado entre dos revoluciones militares (la de 1930 y la de 1943) se ha ido complejizando a lo largo de las décadas. Las primeras lecturas -en clave revisionista- sobre ese proceso político, que se abrió con la revolución de 1930, indicaron que los gobiernos de la Concordancia (1932-1943) no eran más que un sistema de viejos acuerdos de dominación de elencos políticos oligárquicos, orientados a la reincorporación de Argentina al sistema económico internacional mediante relaciones de dependencia con las economías del capitalismo avanzado ${ }^{2}$. A partir de la década de 1960, interpretaciones más complejas repensaron ese ciclo en su especificidad propia como parte de una incompleta restauración constitucional (con irresolubles problemas de legitimidad), y en la que el fraude electoral -una de las imágenes más visibles de esos años- no solo alteró la calidad de esa democracia sino, también, el funcionamiento de las instituciones establecidas dos décadas antes mediante la democratización política de 1912-1916 propiciada por el presidente Roque Saénz Peña ${ }^{3}$. Este grupo de trabajo fue enriquecido en la década de 1980 por otros aportes novedosos desde la historia política, que resaltaron la particular evolución del proceso institucional-electoral, señalando los juegos de poder entre actores cruciales (presidentes, Fuerzas Armadas y partidos políticos). Estas particulares interacciones, según estos análisis, derivaron en un vacío de poder crítico, y favorable, para el golpe militar de 1943 y el nacimiento de otra experiencia política, como fue la del peronismo ${ }^{4}$.

Con el advenimiento de la democracia a partir de 1983, y en paralelo al crecimiento de la producción académica en las universidades, los últimos enfoques recuperaron la primacía de la política para entender la dinámica institucional y las motivaciones de importantes actores durante aquellos años. Algunas de estas lecturas vieron los golpes militares de entreguerras - por otra parte, repetidos en otras latitudes del continente latinoamericano durante el siglo $\mathrm{xx}$ - como una de las posibles salidas entre un variado repertorio de soluciones al problema político en esa coyuntura, y en un contexto ideológicamente polarizado. Si el golpe militar parecía inexorable para interpretaciones pretéritas, este grupo de trabajos tuvo el mérito de instaurar la incertidumbre que rodeó a los acontecimientos y, de esta manera, resaltó las motivaciones y las acciones de los actores políticos más relevantes en esa crítica coyuntura 5 .

\footnotetext{
${ }^{1}$ Deseo agradecer los generosos comentarios que han hecho los árbitros especialistas a una versión preliminar de este trabajo.

${ }^{2}$ Cfr. Jorge Abelardo Ramos, El sexto dominio, 1922-1943, Buenos Aires, Plus Ultra, 1973; Rodolfo Puiggrós, La democracia fraudulenta, Buenos Aires, Jorge Álvarez Editor, 1968.

${ }_{3}^{3}$ Tulio Halperín Donghi, Argentina en el callejón, Buenos Aires, Editorial Arca, 1964; Alberto Ciria, Partidos y poder en la Argentina moderna (1930-1946), Buenos Aires, Jorge Álvarez Editor, 1964; Horacio Schillizzi Moreno, Argentina contemporánea. Fraude y entrega, 1930-1943, Buenos Aires, Editorial Plus Ultra, 1973; Rodolfo Ferrero, Del fraude a la soberanía popular, 1938-1946, Buenos Aires, Ediciones La Bastilla, 1980.

${ }^{4}$ Robert Potash, El ejército y la política en la Argentina: 1928-1945. De Yrigoyen a Perón, Buenos Aires, Hyspanoamérica, 1986; Juan Carlos Portantiero, "Transformación social y crisis de la política", suplemento "La Argentina de los años 30. Momentos y figuras de la crisis", en La Ciudad Futura. Revista de Cultura Socialista, № 4, Buenos Aires, 1987, pp. 14-15; Juan Carlos Torre, La vieja guardia sindical y Perón, Buenos Aires, Sudamericana, 1990.

${ }^{5}$ Juan Carlos Torre, "La crisis argentina de principios de los años cuarenta y sus alternativas. El peronismo y los otros", en Juan Carlos Torre, La Vieja Guardia Sindical y Perón, Buenos Aires, Eduntref, 2006,
} 
Otras lecturas en esta misma línea se centraron en el proceso político-electoral y en las prácticas electorales y partidarias de distintos agentes. Allí, por ejemplo, señalaron asimetrías pronunciadas entre los tres presidentes del periodo "conservador". Si bien todos estaban unidos por su antiyrigoyenismo y formaron parte de los mismos acuerdos partidarios (los de la Concordancia), presentaron especificidades propias que dieron cuenta de un timing diferente en sus respectivos programas presidenciales. Mientras que el primer Presidente constitucional, el general Agustín P. Justo (1932-1938), fue el gran constructor de la alianza política de diversas fuerzas partidarias y supo navegar la restauración constitucional con una retórica democrática (fraude mediante), sus sucesores Roberto M. Ortiz (1938-1942) y Ramón S. Castillo (1942-1943) encarnaron un contrapunto crucial en materia institucional. El binomio electo en septiembre de 1937 demostró en los hechos que sus respectivos programas se orientaban de manera distinta en dar solución a los problemas de legitimidad que acarreaba esa experiencia republicana. El pedido de licencia del presidente Roberto Ortiz - que encarnó un bienio reformista, orientado a la honestidad de las prácticas electorales-en 1940, por problemas de salud, llevó al vicepresidente Ramón Castillo a la presidencia, y desde el poder, este ensayó un programa institucional que, pese a mantenerse en los márgenes del sistema democrático forjado dos décadas antes, pretendía garantizar la hegemonía demócrata (de su propio partido) por sobre la oposición ${ }^{6}$. El general Agustín Justo, primero Presidente y luego como actor central entre bambalinas, fue clave en la alianza política forjada, y en sus años de actividad demostró astucia política y una maestría eminentemente táctica, que como señaló recientemente Fernando Devoto, parecía expresarse mejor en la habilidad de desordenar el juego de sus adversarios que en construir soluciones estables y perdurables $^{7}$. Sin embargo, sus sucesores Roberto M. Ortiz y Ramón S. Castillo demostraron ser competidores reales dentro de la alianza política dando cuenta, además de sus propias habilidades políticas, del papel clave de la institución presidencial como ordenadora del juego político ${ }^{8}$.

Por último, surgieron otras producciones desde la historia política sobre casos provinciales que se han convertido en referencias fundamentales del periodo y con las que este artículo, puntualmente, pretende dialogar. La historiografía regional, en los últimos

apéndice, pp. 135-145 y Fernando Devoto, "Para una reflexión en torno al golpe del 4 de junio de 1943", en Estudios Sociales, № 46, Santa Fe, 2014, pp. 171-186.

${ }^{6}$ Tulio Halperín Donghi, La República imposible (1930-1945), Buenos Aires, Ariel, 2004; Darío Macor, "Partidos, coaliciones y sistema de poder", en Alejandro Cattaruzza (dir.), Crisis económica, avance del Estado e incertidumbre politica (1930-1943), Nueva Historia Argentina, Buenos Aires, Sudamericana, 2001, tomo VII, pp. 49-57; Luciano De Privitellio, "La política bajo el signo de la crisis", en Cattaruzza (dir.), Crisis económica..., op. cit., pp. 97-142; del mismo autor, "La vida política", en Alejandro Cattaruzza (coord.), Argentina. Mirando hacia adentro, Madrid, Fundación Mapfre-Santillana Ediciones, 2012, pp. 39-90. También Ignacio López, "En la 'hora de la espada' y bajo el signo de la reconstrucción. Liderazgo presidencial en tiempos de Agustín Justo, Roberto Ortiz y Ramón Castillo (1932-1943)”, en POSTData, vol. 22, No 2, Buenos Aires, 2017, pp. 437-473.

${ }^{7}$ Devoto, "Para una reflexión...", op. cit., p. 181.

${ }^{8}$ Para un análisis histórico y político del poder presidencial en las democracias modernas, cfr. Richard Neustadt, Presidential Power and the modern presidents. The politics of leadership from Roosevelt to Reagan, New York, The Free Press, 1991 y Stephen Skowronek, The politics presidents make. Leadership from John Adams to George Bush, Cambridge/London, The Belknap Press of Harvard University Press, 1993, pp. 7-8. 
años, ha contribuido al estudio sobre actores y prácticas políticas en escala local, estableciendo diálogos fructíferos con análisis en el ámbito federal ${ }^{9}$.

Este artículo expone algunas conjeturas y busca presentar algunas contribuciones originales. Primero, que en ese segundo periodo constitucional de la restauración de 1932 se dio una evolución y ritmo particular del proceso político. En parte, debido a que la sucesión presidencial dirigida hizo los acuerdos fraudulentos más visibles y estos fueron percibidos cada vez más como ilegítimos ante la opinión pública y el resto de los partidos políticos, acelerando los debates sobre la viabilidad de esa restauración. Pero también, por la reconfiguración del tablero político debido a la desaparición de líderes que garantizaban el sostenimiento de esa particular democracia -ya sea con cuotas de popularidad (Marcelo T. Alvear o Roberto Ortiz) o por su habilidad de gestar acuerdos entre dirigentes y actores cruciales (Agustín Justo)-. En este contexto, como ha señalado Juan Linz tiempo antes, la presencia (o desaparición) de individuos con características y cualidades únicas resultó ser decisiva para la supervivencia de ese tipo de regímenes ${ }^{10}$. En segundo lugar, el artículo busca revaluar las capacidades políticas del presidente Ramón S. Castillo. La historiografía argentina ha tendido a ver en este Presidente un mero reaccionario frente a las políticas reformistas de su sucesor, en aras de evitar el avance de los opositores radicales; o también ha predominado la idea de un presidente debilitado -quintaesencia del pensamiento conservador de los años cuarenta- frente a los sectores nacionalistas de las Fuerzas Armadas que él mismo atrajo, y que estaban ansiosos por conquistar posiciones. Esta fue una de las razones más enfatizadas -junto con la ilegitimidad de los acuerdos políticos y los lineamientos en materia de política exterior- como explicativas del golpe de $1943^{11}$. En este sentido, no solo el artículo pre-

\footnotetext{
${ }^{9}$ Cfr. Darío Macor y César Tcach (comps.), La invención del peronismo en el interior del país, Santa Fe, Universidad Nacional del Litoral, 2003. Sobre alguna producción destacada sobre la política en las provincias durante la década de 1930. Además: Natacha Bacolla, "Nación y provincia en la crisis de la política argentina. Sistema político, partidos y representaciones en la década del 30 (1930-1943)", en X Jornadas Interescuelas/ Departamentos de Historia, Rosario, Actas, 2005; Darío Macor y Susana Piazzesi (eds.), Territorios de la política argentina. Córdoba y Santa Fe, 1930-1945, Santa Fe, Universidad Nacional del Litoral, 2009; Diego Mauro, Reformismo liberal y política de masas. Demócratas progresistas y radicales en Santa Fe (19211937), Rosario, Prohistoria Ediciones, 2013 (para el caso santafesino); María del Mar Solís Carnicer, La cultura política en Corrientes. Partidos, elecciones y prácticas electorales (1909-1930), tesis de doctorado en Historia, Mendoza, Universidad Nacional de Cuyo, Facultad de Filosofía y Letras, 2006 y de la misma autora: Liderazgo y política en Corrientes: Juan Ramón Vidal, 1883-1940, Corrientes, Moglia Ediciones, 2005 (para el caso correntino); Leandro Lichtmajer y Graciana Parra, "Revisando la crisis de los partidos desde una escala provincial. Radicales y conservadores en Tucumán (1940-1943)", en Revista de Historia Americana y Argentina, vol. 49, № 1, Mendoza, 2014, pp. 1-28 y Graciana Parra, "Los demócratas tucumanos: entre el conservadurismo nacional y la Concordancia. La intervención a la provincia de Tucumán, 1933-1934", en Anuario del Centro de Estudios Históricos "Prof. Carlos S. A. Segreti”, № 11, Córdoba, 2011, pp. 85-106 (para el caso tucumano); Adriana Kindgard, Alianzas y enfrentamientos en los orígenes del peronismo jujeño: estructura de poder, partidos políticos, Jujuy, Universidad Nacional de Jujuy, 2001 (para el caso jujeño).

${ }^{10}$ Juan Linz, La quiebra de las democracias, Madrid, Alianza Editorial, 1996, p. 16.

${ }^{11}$ Sobre este punto, véanse memorias de los contemporáneos: Carlos Ibarguren, La historia que he vivido, Buenos Aires, Editorial Peuser, 1955, pp. 630-631; Federico Pinedo, En tiempos de la República, Buenos Aires, Editorial Mundo Forense, 1946, tomo I, pp. 180-193; Nicolás Repetto, Mi paso por la politica. De Uriburu a Perón, Buenos Aires, Santiago Rueda Editor, 1957, pp. 184-195; Félix Weil, El enigma argentino, Buenos Aires, Ediciones Biblioteca Nacional, 2010, pp. 99-102.
} 
tende vincular al programa presidencial de Ramón Castillo con el universo sáenzpeñista y conservador de dos décadas antes y complejizar su visión de la política de más largo plazo; sino que, además, busca enfatizar los intentos del último Presidente conservador de reconstruir el tejido político-partidario. Particularmente a través de una revaluación de sus capacidades de iniciativa política, en un contexto de creciente polarización y a través de la política en algunos casos provinciales (Corrientes, Jujuy y Tucumán) ${ }^{12}$.

El artículo se divide en cinco secciones: en la primera, repasa los rasgos centrales que la historiografía presentó sobre la política argentina durante la década de 1930; en la segunda sección, explica el ascenso al poder del vicepresidente Ramón Castillo, luego de la enfermedad de su antecesor; en la tercera parte, analiza algunos casos provinciales donde fue notorio el avance de las fuerzas conservadoras en los espacios subnacionales; en la cuarta sección, retoma los últimos meses del presidente Ramón Castillo y sus medidas políticas centrales y, finalmente, presenta algunas conclusiones.

\section{LA RESTAURACIÓN CONSTITUCIONAL DE LA DÉCADA DE 1930}

Y SUS PROBLEMAS DE LEGITIMIDAD

El triunfo de la revolución de 1930 y el hundimiento del segundo gobierno radical de Hipólito Yrigoyen pronto habían hecho visibles dos proyectos políticos en el seno de los victoriosos de la revolución septembrina. Por un lado, el fallido plan corporativista de José Félix Uriburu, que ante la imprecisión ideológica y la oposición creciente del arco político -aún de los triunfadores golpistas-, terminó por naufragar ${ }^{13}$. Pronto sus aspiraciones fueron desechadas por el triunfo radical de abril de 1931 en la provincia de Buenos Aires, y los deseos del dictador dieron paso a las gestiones de otros sectores políticos del golpe que convocaron a elecciones en noviembre de ese año.

Frente a la prohibición del gobierno provisional de una fórmula encabezada por Marcelo T. de Alvear y que contuviese a los despojados del poder tiempo antes, el radicalismo optó por la abstención electoral, posibilitando que en las elecciones presidenciales compitieran con mayores chances de obtener el triunfo las coaliciones formadas por general Agustín P. Justo y Lisandro de la Torre. El primero encabezó un frente electoral de fuerzas antiyrigoyenistas, la Concordancia; el segundo, junto con el socialista Nicolás Repetto, logró coaligar a las fuerzas progresistas y de izquierda democrática en la Alianza Civil ${ }^{14}$.

En esas elecciones de 1931 se impuso el general Agustín Justo. Su gobierno durante 1932 y 1938, surgido de los comicios condicionados por la abstención del radicalismo, encaró la difícil tarea de restaurar la institucionalidad democrática, sustentada por una

\footnotetext{
${ }^{12}$ Sobre la especificidad de lo político, cfr. Lawrence Stone, "The revival of the Narrative Reflexions on a New Old History", in Past and Present, No 82, Oxford, 1979, pp. 3-24.

${ }^{13}$ Sobre el proyecto uriburista cfr. Alfredo Galleti, La realidad argentina en el siglo xx, Buenos Aires, FCE, tomo I, 1961, pp. 76-132; María Dolores Béjar, El régimen fraudulento. La política en la provincia de Buenos Aires, 1930-1943, Buenos Aires, Siglo XXI, 2005, pp. 61-84; Federico Finchelstein, Fascismo transatlántico. Ideología, violencia y sacralidad en Argentina y en Italia, 1919-1945, Buenos Aires, FCE, 2010, pp. 73-146.

${ }^{14}$ Schillizzi, op. cit., pp. 77-109; Ferrero, op. cit., pp. 8-31.
} 
legitimidad de origen frágil, y coartada tanto por los levantamientos radicales de los años 1932 y 1933 como por impugnadores e intelectuales que desde la derecha del espectro político atacaban las bases mismas del sistema democrático ${ }^{15}$. La vuelta del radicalismo a la arena electoral en 1935 generó que, aún desde una retórica legalista y democrática, el gobierno de Agustín Justo condicionase mediante ciertos mecanismos institucionales y permisividad de prácticas fraudulentas, el retorno del radicalismo al poder y limitase su inserción institucional. La sucesión presidencial hacia el año 1936 debía ser conducida, según el Presidente saliente, para garantizar la continuidad de la Concordancia, y su posible retorno al poder luego de un mandato constitucional ${ }^{16}$.

La cuestión de la legitimidad fue central en esa restauración. Como señalaron Darío Macor, Susana Piazzesi ${ }^{17}$ y María D. Béjar ${ }^{18}$ el fraude electoral operó como un instrumento privilegiado en la reproducción de las relaciones de poder, en la sucesión y control electoral, pero, a su vez, como mecanismo para dirimir disputas intraélite ${ }^{19}$. La experiencia del justismo, en este sentido, fue una respuesta a la crisis del sistema institucional abierta a raíz de la caída de Hipólto Yrigoyen en 1930 que se mantuvo bajo el marco de la tradición liberal, aun cuando intelectuales y militares nacionalistas buscaban nuevas formas más autoritarias de organización política ${ }^{20}$. Sin embargo, pese a este refugio quedó atrapado en un dilema que fue inherente al poder político de toda la década: cómo controlar el poder en nombre de una tradición cuya faceta democrática había permitido la consolidación de un partido predominante (UCR), y que, de abrirse el juego electoral, pudiese reconstruir el poder que le fuera despojado en $1930^{21}$.

Desde el punto de vista sistémico, los acuerdos que emergieron a partir de la restauración constitucional posgolpe estaban configurados por dos datos "estructurales" de la democratización abierta en 1912-1916: primero, dieciocho años de ejercicio de democracia electoral habían dado lugar a una fuente de legitimidad difícil de obviar; segundo, el predominio electoral de la UCR, que había vuelto a confirmarse en las elecciones de abril de 1931 en la provincia de Buenos Aires ${ }^{22}$. La imposibilidad de armonizar la fuente

${ }^{15}$ Darío Macor y Susana Piazzesi, "Organizaciones partidarias, elecciones y elites políticas. Santa Fe (Argentina), 1930-1943”, en Boletín Americanista, año LVII, № 57, Barcelona, 2007, pp. 107-132.

${ }^{16}$ Macor, "Sistemas de partidos...", op. cit., pp. 63-34; Privitellio, "La vida política...”, op. cit., pp. 57-58; Darío Macor y Susana Piazzesi, "La cuestión de la legitimidad en la construcción del poder en la Argentina de los años treinta", en Cuadernos Sur Historia, N³4, Bahía Blanca, 2005, pp. 9-34. Sobre Agustín Justo cfr. Luciano de Privitellio, Agustín P. Justo. Los nombres del poder, Buenos Aires, FCE, 1997; Rosendo Fraga, El general Justo, Buenos Aires, Emecé Editores, 1993.

${ }^{17}$ Macor y Piazzesi, "La cuestión de la legitimidad...", op. cit., pp. 9-11.

${ }^{18}$ María Dolores Béjar, "La construcción del fraude y los partidos políticos en la Argentina de los años treinta", en Cuadernos del CISH, No 15-16, La Plata, 2004, pp. 65-97.

${ }^{19}$ María Dolores Béjar, "El régimen fraudulento desde la dinámica facciosa del conservadurismo bonaerense", en Revista de Historia, año 1, No 1, Mar del Plata, 2005, pp. 1-24. Disponible en www.historiapolitica.com/datos/biblioteca/bejar.pdf [fecha de consulta: 2 de septiembre de 2017].

${ }^{20}$ Ana Virginia Persello, "Los gobiernos radicales: debate institucional y práctica política”, en Ricardo Falcón (dir.), Democracia, conflicto social y renovación de ideas (1916-1930), Buenos Aires, Sudamericana, Nueva Historia Argentina, 2000, tomo vi, pp. 59-99; de la misma autora, El partido radical. Gobierno y oposición, 1916-1943, Buenos Aires, Siglo XXI, 2004, pp. 175-205.

${ }^{21}$ Macor y Piazzesi, "La cuestión de la legitimidad...", op. cit., pp. 9-11.

${ }^{22}$ Op. cit., pp. 11-13. 
de legitimidad democrática, el predominio radical en el electorado y la pretensión del oficialismo de montar una máquina de fraude selectivo fueron los factores constituyentes del dilema del sistema político. Como señalaron Darío Macor y Susana Piazzesi, la puesta entre paréntesis de la democracia electoral con el ejercicio sistemático del fraude garantizó la reproducción en el poder, pero afectó, al mismo tiempo, la legitimidad del sistema, obligando al gobierno a fortalecer y destacar otros dispositivos de legitimación ${ }^{23}$.

Como parte de la maquinaria fraudulenta, las elecciones presidenciales de septiembre de 1937 se transformaron en un eslabón perfecto para garantizar la sucesión de la Concordancia. Fueron comicios viciados, con fuertes restricciones al ejercicio de la libertad electoral, que demostraron el poder de las maquinarias partidarias que solo sobrevivían con la manipulación electoral y que estaban fuertemente arraigadas en los espacios provinciales ${ }^{24}$. En este contexto, emergieron nuevas discusiones en el elenco concordancista sobre los candidatos a suceder al presidente Justo, que, en última instancia, tuvo la última decisión sobre los candidatos. La coalición de gobierno, como señaló Darío Macor, gozó de particularidades propias. La Concordancia tuvo un comportamiento inorgánico y actuó más bien como un "bloque interparlamentario" que accedía a los cargos en listas diferenciadas en el ámbito provincial y nacional -solo unidos por los Ejecutivos-. Nunca actuó ni como un partido único, ni como un frente orgánico, ni como una coalición de gobierno cohesionada y articulada ${ }^{25}$. Durante un decenio, el liderazgo del general Agustín Justo fue crucial para la estabilidad y unidad de las dispersas agrupaciones. Sin embargo, durante un breve lapso, el presidente Roberto Ortiz, y luego su sucesor, Ramón Castillo, fueron competidores reales por el manejo de recursos políticos y simbólicos e intentaron imprimir sus propias orientaciones al armado políticoelectoral, desde la presidencia. Nuevamente, la institución presidencial, por sus recursos legales y políticos, alteró el equilibro de fuerzas dentro de la coalición al menos durante dos periodos definidos: 1939-1940, bajo la órbita reformista de Roberto Ortiz; y durante 1941-1943, bajo el contraataque conservador de Ramón Castillo ${ }^{26}$.

Los partidos integrantes de la Concordancia fueron, en tanto, bastante definidos. El principal socio fue el Partido Demócrata Nacional (PDN) que en sí mismo representó una coalición ya que reunía a agrupaciones provinciales que a diferentes tradiciones y prácticas políticas ${ }^{27}$. Un segundo núcleo dentro de la coalición concordancista fue el antipersonalismo radical. Las agrupaciones antiyrigoyenistas provinciales escindidas formalmente de la Unión Cívica Radical del comité nacional (UCR-CN) apoyaron a Agustín Justo en noviembre de 1931, pero tampoco pudieron estructurarse en un partido

\footnotetext{
${ }^{23}$ Macor y Piazzesi, "La cuestión de la legitimidad...", op. cit., pp. 13-14. Cfr. también Susana Piazzesi, Conservadores en provincia. El iriondismo santafesino. 1937-43, Santa Fe, Universidad Nacional del Litoral, 2010.

${ }^{24}$ Julio César Melón Pirro, "Legislación y práctica electoral en la década de 1930. La Ley trampa y el fraude patriótico", en Julio César Melón Pirro y Elisa Pastoriza (eds.), Los caminos de la democracia. Alternativas y Prácticas Políticas 1900- 1943, Buenos Aires, Biblos, 1996, pp. 163-182.

${ }^{25}$ Macor, "Partidos, coaliciones...", op. cit., pp. 52-53.

${ }^{26}$ Op. cit., pp. 63-64. También Ignacio López, La república del fraude y su crisis. Política y poder en tiempos de Roberto M. Ortiz y Ramón S. Castillo (Argentina, 1938-1943), Rosario, Prohistoria, 2018.

${ }^{27}$ Macor, "Partidos, coaliciones...", op. cit., pp. 61-62. María Dolores Béjar, "Otra vez la historia política. El conservadurismo bonaerense en los años treinta", en Anuario del IEHS, No 1, Tandil, 1986, pp. 199-227.
} 
único ni adquirir una organización institucionalizada en el ámbito nacional, salvo en periodos transitorios como 1932-1933 y 1943. Su peso en el frente estuvo dado no solo por su caudal electoral en el Litoral, en Capital Federal y en la región Noroeste, sino por su capacidad de competencia con el radicalismo alvearista por la tradición partidaria y elementos simbólicos ${ }^{28}$. Por último, el tercer núcleo partidario dentro del espacio concordancista fue el socialismo independiente (PSI). Esta disidencia del Partido Socialista, gestada algunos años antes, estaba conformada por un núcleo de dirigentes capitalinos y bonaerenses que lograron sobrerrepresentación en el gobierno nacional. En un primer momento, por la capacidad electoral demostrada en la Capital Federal, y luego por su nivel de exposición pública, ministerial y legislativa, que impactaba en la opinión nacional. La gestión exitosa de sus figuras nacionales en carteras clave, como Antonio de Tomaso en Agricultura o Federico Pinedo en Hacienda, además de un puñado de legisladores en el Congreso, les otorgó la impronta de policy makers ${ }^{29}$. A estos dirigentes se debió gran parte de la reestructuración de la política económica de la década: leyes de protección social, programas macroeconómicos (como los de 1932-1933 y el de 1940) y creación de instituciones clave en materia de política monetaria como el Banco Cen$\operatorname{tral}^{30}$.

Los candidatos oficialistas para las elecciones presidenciales de 1937, de las que debían salir los sucesores de Agustín Justo, fueron Roberto M. Ortiz y Ramón S. Castillo. Debido a los acuerdos políticos forjados en la restauración de 1931, y la influencia del general Justo, el antipersonalista encabezó la fórmula que sería secundada por un candidato conservador. Los especialistas advirtieron que el primer término respondió a una decisión personal del Presidente y se debía a razones no solo políticas sino, también, personales. El candidato debía tener un perfil radical (entiéndase, antiyrigoyenista) con el doble objetivo de ser más atractivo al electorado, y de fortalecer al grupo más débil dentro de la coalición gobernante (y manejado directamente por Agustín Justo). Roberto Ortiz, había sido un antiguo militante radical, funcionario del presidente Marcelo T. Alvear (1922-1928) y más recientemente, ministro de Hacienda de Justo, pero, sobre todo, siempre fue un hombre leal. El Vicepresidente, en cambio, debía cumplir otro requisito clave: ser un conservador nato y equilibrar el apoyo de los partidos demócratas de las provincias. Justo, en principio, buscó la designación de un demócrata "manipulable" que fuese un nexo fluido con el PDN. Encontró a ese hombre en la figura de su ministro de Agricultura, Miguel Ángel Cárcano. Los biógrafos de Justo advirtieron que la decisión de elegir a un demócrata cercano se debía a los claros deseos del General de retornar a la presidencia en 1944, luego de un mandato constitucional, como permitía

\footnotetext{
${ }^{28}$ Sobre el antipersonalismo, cfr Ana Virginia Persello, El partido radical. Gobierno y oposición, 19161943, Buenos Aires, Siglo XXI Editores, 2004 y Elena Piñeiro, Creyentes, herejes y arribistas. El radicalismo en la encrucijada, 1924-1943, Rosario, Prohistoria Ediciones, 2014.

${ }^{29}$ Macor, "Partidos, coaliciones...", op. cit., p. 66.

${ }^{30}$ Horacio Sanguinetti, Los socialistas independientes, Buenos Aires, Editorial de Belgrano, 1981; Juan José Llach, "El Plan Pinedo de 1940, su significado histórico y los orígenes de la economía política del peronismo", en Desarrollo Económico, vol. 23, № 92, enero-marzo, Buenos Aires, 1984, pp. 515-558; Juan Carlos Korol, "La economía", en Alejandro Cattaruzza (dir.), Crisis económica, avance del Estado e incertidumbre política (1930-1943), Buenos Aires, Editorial Sudamericana, Nueva Historia Argentina, 2001, tomo VII, pp. 1747.
} 
la Constitución Nacional. Para eso era central tener a un conservador de su lado, en caso de que Roberto Ortiz no terminase su mandato ${ }^{31}$. Sin embargo, la mesa directiva del PDN propuso a un hombre fuerte, poco influenciable por Justo: el senador salteño, presidente provisional del Senado y presidente de la mesa directiva del PDN: Robustiano Patrón Costas. El doble veto de la candidatura presidencial -el de Justo hacia Patrón Costas, por considerarlo demasiado independiente; y el de los demócratas hacia Miguel A. Cárcano, por considerarlo demasiado influenciable-, terminó en un impasse solo resuelto hacia junio de 1937, cuando las partes, con el aval de Justo y de Ortiz, decidieron nominar a Ramón S. Castillo como Vicepresidente, por ese entonces ministro de Justicia e Instrucción Pública y también de la cartera de Interior ${ }^{32}$.

A diferencia de la trayectoria pública de Roberto Ortiz, Ramón Castillo había cultivado una vida académica y judicial y su ingreso a la política fue tardío. Aunque eso no le impidió desplegar dotes de astucia y moverse con facilidad en los círculos políticos más altos de la república. Más aún, el Vicepresidente hizo uso de los recursos constitucionales y políticos disponibles para consolidar su programa político desde la presidencia.

Los candidatos oficialistas triunfaron sin sorpresa en las elecciones de septiembre de 1937. Roberto Ortiz gobernó el país por dos años hasta que a mediados de 1940 debió abandonar el poder de modo temporal por el agravamiento de su estado de salud. Su breve experiencia, sin embargo, fue un hito en la restauración constitucional percibida por muchos de sus contemporáneos como intento reformista que buscó garantizar prácticas electorales más honestas ${ }^{33}$. El Presidente propuso algunos proyectos legislativos, como el de reforma de los partidos políticos para sanear problemas vinculados a la práctica política originada por la democratización de 1912-1916 ${ }^{34}$, e intervino algunos distritos como Catamarca - provincia de su Vicepresidente- y Buenos Aires - gobernada por el poderoso Partido Conservador- en aras de garantizar prácticas electorales más honestas y anular los resultados fraudulentos ${ }^{35}$.

Empero, Ramón Castillo, que reemplazó a Roberto Ortiz a mediados de ese año, cambió el rumbo de la política presidencial. Desde el poder, detuvo los avances de la política de democratización de su sucesor, buscó acercarse con sectores nacionalistas

\footnotetext{
${ }^{31}$ Fraga, El general Justo..., op. cit., p. 426 y ss.; Privitellio, Agustín P. Justo..., op. cit., pp. 60-65. La idea de que Roberto Ortiz podía no terminar su mandato por problemas de salud es referida en algunas entrevistas de contemporáneos como Adolfo Mugica. El candidato presidencial tuvo dos episodios de descompensación durante la campaña electoral. Cfr. entrevista a Adolfo Mugica por Luis Alberto Romero, 1971, en Archivo Historia Oral, Universidad Torcuato Di Tella, caja 6-2, pp. 300-315.

${ }^{32}$ Véase Félix Luna, Ortiz: Reportaje a la Argentina opulenta, Buenos Aires, Sudamericana, 1979, p. 19; Fraga, op. cit., p. 426 y ss.; Potash, op. cit., pp. 155-156.

${ }^{33}$ Luna, Ortiz..., op. cit., pp. 20-25; Privitellio, "La política bajo el signo...”, op. cit., pp. 126-133; Ignacio López, "El desmantelamiento del fraude patriótico: las intervenciones federales durante los años de Roberto M. Ortiz (1938-1940)", en Anuario del Centro de Estudios Históricos “Carlos S. A. Segreti”, No 11, Córdoba, 2011, pp. 107-127.

${ }^{34}$ Ana Virginia Persello, "Los gobiernos radicales...", op. cit., pp. 59-99; Ana Virginia Persello, “Acerca de los partidos políticos, 1890-1943”, en Anuario del IEHS, № 15, Tandil, 2000, pp. 239-266; Ignacio López, “"Argentinizar' la democracia, defender las instituciones. Notas sobre algunos proyectos legislativos del presidente Roberto M. Ortiz”, en Boletín Americanista, vol. 1, № 70, Barcelona, 2015, pp. 169-189.

${ }^{35}$ López, "El desmantelamiento del fraude...", op. cit., pp. 107-127.
} 
del Ejército -en aras de contrarrestar la influencia del general Justo en las fuerzas- y ensayó el último intento de las fuerzas conversadoras de dirigir los destinos de la república en un posible escenario de hegemonía demócrata y con participación subordinada de los radicales. Sin embargo, el Vicepresidente fue heredero de los resultados de la democratización de 1912-1916 y, si bien fue permisivo ante las prácticas fraudulentas, su diagnóstico sobre los problemas de la democracia argentina, y sus posibles soluciones, se mantenían en el panorama que habían forjado los reformistas dos décadas antes, como demostró su Anteproyecto de Código Político elaborado a inicios de $1943^{36}$.

\section{El ascenso de Ramón S. CASTillo a la presidencia: HaCia Un PANORAMA DE HEGEMONÍA DEMÓCRATA}

El 3 de julio de 1940, el presidente Roberto Ortiz cedió provisionalmente el mando al vicepresidente Ramón Castillo por un agravamiento de su estado de salud, producto de un cuadro de diabetes. El Presidente se encontraba en el cenit de su programa reformista, luego de que en las elecciones de marzo de ese año el radicalismo recuperase la mayoría de las bancas en la Cámara de Diputados de la Nación, en un hecho histórico ${ }^{37}$. Nadie supuso que la excepcionalidad (la enfermedad del titular del Ejecutivo Nacional) se transformaría en una situación permanente de la política nacional durante los tres años siguientes; ni tampoco que el cambio de riendas en el Ejecutivo Nacional traería un giro político tan drástico que afectaría irremediablemente el curso de los acontecimientos. En el mismo mes que se iniciaba el ataque aéreo de la Luftwaffe a la Royal Navy británica y se iniciaba la denominada "Batalla de Inglaterra" en el Viejo Continente, los periódicos argentinos titulaban la noticia de la licencia del Presidente como una "necesidad de reposo" absolutamente "transitoria" hasta que se recuperase de un "enfriamiento" que lo aquejaba desde junio ${ }^{38}$.

Lo cierto fue que el demócrata catamarqueño, que iba a tener en sus manos la investidura presidencial por casi tres años - primero provisoriamente y a partir de junio de 1942 en forma definitiva-, no solo había forjado su trayectoria política en forma distinta a la de su antecesor, sino que poseía concepciones distintas sobre la política federal y los cursos de acción a tomar. Había debutado en la escena nacional en el dramático año 1930 y su trayectoria no había sido gestada ni en un comité partidario ni en órganos deliberativos como la de Roberto Ortiz. Su prestigio académico y profesional, como profesor y jurista, habían precedido a su actividad política. La "testarudez" de ese an-

\footnotetext{
${ }^{36}$ Sobre el sáenzpeñismo véase, por ejemplo, Miguel Ángel Cárcano, Saénz Peña. La revolución por los comicios, Buenos Aires, Hyspanoamérica, 1976; Fernando Devoto, "De nuevo el acontecimiento: Roque Sáenz Peña, la reforma electoral y el momento político de 1912", en Boletín del Instituto de Historia Argentina y Americana "Dr. Emilio Ravignani", № 14, Buenos Aires, 1996, pp. 93-113 y María Sáenz Quesada, Roque Sáenz Peña: el presidente que forjó la democracia moderna, Buenos Aires, Sudamericana, 2014.

${ }^{37}$ Ministerio del Interior, Las Fuerzas Armadas restituyen el imperio de la soberanía popular. Las elecciones generales de 1946, Buenos Aires, Imprenta de la Cámara de Diputados, 1946, tomo I, pp. 599-603; Darío Cantón, Elecciones y partidos políticos en la Argentina. Historia, interpretación y balance: 1910-1966, Buenos Aires, Siglo XXI, 1973, p. 119.

${ }^{38}$ La Nación, Buenos Aires, 4 de julio de 1940.
} 
ciano "caprichoso", como señaló Halperín Donghi ${ }^{39}$, no era nada más ni menos que un egoísmo y autoimagen de superioridad intelectual forjada en las bibliotecas, aulas y juzgados: una voz experimentada y erudita por fin lograba tener una cuota nada desdeñable de poder real ${ }^{40}$.

El Vicepresidente había obtenido sus primeros cargos judiciales a fines de siglo XIX; ascendió a camarista y luego a juez federal en lo comercial en Capital Federal hacia 19101912. Una notable "austeridad", pero también "energía y severidad" fueron signos visibles en su carrera como magistrado durante esos años, como lo demuestran algunos episodios en suelo bonaerense, donde se enfrentó a la autoridad política cuando fue necesario ${ }^{41}$.

Otra dimensión de su currículo lo constituye la vida académica. La extensa experiencia en la vida universitaria se inició en 1907 como auxiliar en cátedras de Derecho Comercial en la Universidad de Buenos Aires y en la Universidad de La Plata entre 1910 y 1915. Fue autor de varias publicaciones especializadas. Hacia 1923 alcanzó un encumbrado lugar académico al ser nombrado decano de la Facultad de Derecho de la Universidad de Buenos Aires, cargo que ocupó hasta 1928. Durante esta etapa de su vida, la intransigencia y férreo legalismo fueron características sobresalientes de su desempeño profesional $^{42}$.

Durante el golpe militar de José Félix Uriburu, fue nombrado interventor en la provincia de Tucumán y allí realizó gestiones ante las autoridades nacionales para lograr la protección aduanera al azúcar, medida que impactó principalmente entre los industriales y los productores cañeros ${ }^{43}$. El debut político como comisionado federal en Tucumán resultó exitoso y hacia 1932 fue electo senador nacional por su provincia natal en el marco de la restauración surgida con el gobierno de Agustín Justo. Para esa altura, tenía cincuenta y ocho años y era un hombre prominente en el ámbito jurídico y universitario.

Ni su ingreso tardío al Partido Demócrata Nacional; ni su perfil bajo, severo y frugal; ni sus orígenes académicos o universitarios, impidieron que se moviese con energía y astucia en las bambalinas de la política nacional. Había pasado una década desde que conociera a Agustín Justo, cuando este aún era ministro de Guerra de Marcelo T. de Alvear y él, decano de la Facultad de Derecho. A partir de allí un vínculo amistoso y lazos de respeto mutuo surgieron entre ambos hombres. Es así que, a partir de enero de 1936, fue convocado por el presidente Justo para asumir como ministro de Justicia e Instrucción Pública y a partir de agosto logró sumar la cartera del Interior -a raíz de la salida

${ }^{39}$ Halperin, Argentina en el callejón..., op. cit., p. 100.

${ }^{40}$ Para una reseña biográfica de Ramón Castillo, Cfr. Edmundo Gutiérrez, Bosquejos biográficos del Dr. Ramón S. Castillo, Buenos Aires, Imprenta López, 1941 y Gustavo Levene, "Ramón S. Castillo", en Gustavo Levene (ed.),Presidentes argentinos, Buenos Aires, Compañía General Fabril Editora, 1961, pp. 227-233.

${ }^{41}$ Gutiérrez, op. cit., p. 27 y ss. El autor relata el episodio donde Ramón Castillo ordenó el arresto provisorio de un diputado provincial ugartista en un tiroteo. Pese a ser liberado por el juez Ramón Castillo, su decisión lo enfrentó con la maquinaria oficialista. Cfr. también el mismo episodio en John White, Argentina. The Life Story of a Nation, New York, The Viking Press, 1942, p. 167.

${ }^{42}$ Gutiérrez, op. cit., pp. 146-147. Cfr. también Sandro Olaza Pallero, "Ramón S. Castillo, decano de la Facultad de Derecho de Buenos Aires. Una reacción conservadora al orden reformista universitario", en Tulio Ortiz (coord.), Hombres e Ideas de la Facultad de Derecho de la Universidad de Buenos Aires, Buenos Aires, Ediciones Facultad de Derecho UBA, 2016, pp. 185-213.

${ }^{43}$ Lichtmajer y Parra, op. cit., pp. 1-28. 
de Leopoldo Melo del gabinete- la que conservó hasta mediados de 1937, momento en que renunció para dedicarse de lleno a la campaña presidencial. Su nombre expresaba por esos años la quintaesencia del conservadurismo norteño, además de demostrar durante su gestión ministerial un carácter férreo, pero, a la vez, conciliador ${ }^{44}$.

Cuando su nombre como candidato a Vicepresidente de la fórmula de la Concordancia -debido al obstáculo generado entre las candidaturas vetadas de Robustiano Patrón Costas y de Miguel A. Cárcano para el mismo puesto entre Agustín Justo y la mayoría demócrata- se hizo efectiva a mediados de 1937, el diario conservador La Fronda destacó su "sobriedad y severidad" y una carrera judicial, académica y política "sin vacilaciones" 45. El periodista estadounidense John Gunther, en su paso por Argentina, tuvo también la oportunidad de conocerlo de forma personal cuando ya era Presidente provisorio y advirtió su carácter "montañero", de "zorro" y sus ideas esencialmente "nacionalistas"46.

Durante los dos años en actividad del presidente Roberto Ortiz, mantuvo un austero segundo plano en la política nacional: su papel, como el de la mayoría de los vicepresidentes en la historia argentina, estuvo acotado a labores en el Senado de la nación y a reemplazar al Ejecutivo en caso de ausencia transitoria ${ }^{47}$. Asistió a ceremonias acompañando al Presidente - muchas de ellas relacionadas con las Fuerzas Armadas-y reemplazó en algunos episodios donde este pidió licencia breve por cuadros de enfermedad transitorios. Aun durante el conflicto en Catamarca entre diciembre de 1939 y febrero de 1940 -cuando Ortiz amenazó al gobernador demócrata Juan Gregorio Cerezo, y luego envió la intervención federal-, mantuvo una postura firme, pero no agresiva contra el primer magistrado, ateniéndose a los preceptos legales. En aquella oportunidad dio su respaldo público al gobernador catamarqueño, justificando su actuación por el mandato de autonomías provinciales. Luego, el vínculo con Ortiz se enfrió, y los encuentros con el Mandatario se dilataron, aunque siempre se mantuvieron en un ambiente de respeto mutuo y cordialidad ${ }^{48}$.

Enfrentó su primera crisis al mando del gobierno cuando estalló el escándalo de El Palomar, que involucró al ministro de Guerra de Ortiz, Carlos Márquez y a una serie de diputados conservadores y radicales, además de civiles. El caso de corrupción adquirió connotaciones políticas, y el Presidente presentó su renuncia (no indeclinable) a fines de agosto en solidaridad con su Ministro, aunque esta fue rechazada por unanimidad en la Asamblea Legislativa ${ }^{49}$. La estatura moral del Presidente se vio fortalecida, sin embar-

${ }^{44}$ Elena Piñeiro, Los radicales antipersonalistas. Historia de una disidencia, tesis de doctorado en Historia, Buenos Aires, Universidad Torcuato Di Tella, pp. 240-241; Gutiérrez, op. cit., pp. 211-213.

${ }^{45}$ La Fronda, Buenos Aires, 26 de junio de 1937.

${ }^{46}$ John Gunther, Inside Latin America, New York/London, Harper \& Brothers, 1942, p. 291.

${ }^{47}$ Para un análisis jurídico e histórico de la institución del Vicepresidente, Cfr. Mario Serrafero, El poder y su sombra. Los vicepresidentes, Buenos Aires, Editorial de Belgrano, 1999.

${ }^{48}$ Algunos testimonios dan cuenta de que las relaciones entre Roberto Ortiz y Ramón Castillo durante el primer semestre de 1940 y aun durante el periodo posterior al pedido de licencia siempre estuvieron enmarcadas en un trato cordial. Cfr. entrevista a Diógenes Taboada por Luis Alberto Romero, Buenos Aires, 1971, en Archivo Historia Oral, caja 4-3, pp. 15-16. También véanse impresiones de Vicente Solano Lima y Adolfo Mugica, en Luna, Ortiz..., op. cit., pp. 146-147.

${ }^{49}$ El hecho delictivo consistió en que dos particulares, Jacinto Baldassarre Torres y Néstor Luis Casás lograron comprar doscientas veintidós hectáreas en El Palomar, partido de San Martín (provincia de Buenos Aires) 
go, aceptó una reconfiguración del gabinete a partir de septiembre, en el que ingresaron hombres de alto perfil como Federico Pinedo y Julio A. Roca (h), y salieron los ministros más “orticistas" como Carlos Márquez (Guerra), Diógenes Taboada (Interior), José María Cantilo (Relaciones Exteriores) y Luis Barberis (Obras Públicas).

Las elecciones en las provincias de Santa Fe y Mendoza durante diciembre de 1940 y enero de 1941, cuyo resultado fue la imposición de las fuerzas conservadoras en esos distritos, fueron interpretadas para los partidos políticos opositores y la opinión pública en general, como un retroceso en materia de prácticas electorales y el retorno a los viejos vicios políticos. En enero de 1941, renunciaron los ministros Federico Pinedo y Julio Roca (h), y hacia febrero se sumó la renuncia del interventor de la provincia de Buenos Aires, el escritor Octavio Amadeo, por una serie de desavenencias políticas con el Vicepresidente ${ }^{50}$.

La crisis del verano de 1941 tuvo como campo de batalla la Cámara de Diputados de la Nación, en cuyo recinto las voces de la oposición resonaron sobre los nuevos lineamientos de la política presidencial. Allí el ministro del Interior, el antipersonalista Miguel Ángel Culaciati, defendió las autonomías provinciales, la nueva política del Vicepresidente y la no intromisión en asuntos políticos por parte del gobierno federal ${ }^{51}$. La crisis tuvo su punto culminante cuando Roberto Ortiz, desde el reposo, lanzó en la mañana del 12 de febrero un "manifiesto" en el que denunciaba la complicidad del Poder Ejecutivo interino en las elecciones fraudulentas recientes ${ }^{52}$.

Días después de la crisis se activó una nueva embestida de los senadores oficialistas contra el presidente Roberto Ortiz: la creación de una comisión para que investigase su "verdadero" estado de salud. El objetivo de esta iniciativa parlamentaria era reclamar supremacía senatorial para un eventual caso constitucional que pudiese plantearse por un retorno forzado, y recopilar suficiente información para juzgarlo en un eventual juicio político por inhabilidad. Los senadores estaban convencidos de que, si se llevaba a cabo la política de democratización del Poder Ejecutivo, la propia supervivencia de la coalición oficial estaría en riesgo. De algún modo, el conflicto del Senado también daba cuenta de un clivaje creciente que existía al interior del oficialismo: aquellos sectores reformistas que encarnaba el Presidente y parte de sus ministros; y los reaccionarios o conservadores, liderados por el Vicepresidente y el núcleo duro del PDN. Los resultados de la comisión aprobados durante abril de 1941 demostraron que Ortiz poseía una severa e irreversible ceguera que le impediría retornar al poder, pese a que los documentos de la comisión no tuvieron resultados concretos ${ }^{53}$.

a María Antonieta Pereyra Iraola de Herrera Vegas y a María Luisa Pereyra Iraola de Herrera Vegas a sesenta y cinco centavos el metro cuadrado y en el mismo momento de firmar las escrituras se la vendieron al gobierno nacional a un peso diez el metro cuadrado, obteniendo una ganancia neta de un millón de pesos, repartido entre varios involucrados entre los cuales figuraban diputados nacionales y un general del Ejército. Cfr. Osvaldo Bayer, "Palomar: negociado que conmovió a un régimen", en Todo es Historia, N 2, Buenos Aires, 1976, pp. 68-93.

${ }^{50}$ Octavio Amadeo a Ramón S. Castillo, La Plata, 31 de enero de 1941 en La Nación, Buenos Aires, 1 de febrero de 1941.

${ }^{51}$ Honorable Cámara de Diputados de la Nación, Diario de sesiones, 5 de febrero de 1941, pp. 53-56.

${ }^{52}$ Roberto Ortiz, "Manifiesto", en Hechos e Ideas, No 39, Buenos Aires, febrero de 1941, pp. 406-408. Cfr. Comisión de Homenaje, El presidente Ortiz y el Senado de la Nación, Buenos Aires, Buenos Aires Herald, 1941.

${ }^{53}$ Honorable Cámara de Senadores de la Nación, Diario de sesiones, 24 de abril de 1941, pp. 735-754. 
Esa crisis del verano, sin embargo, terminó con algunas redefiniciones del tablero político y con un claro perdedor: el presidente Roberto Ortiz. Si bien fue unánime la condena a la acción senatorial, los miembros de la comisión lograron poner al descubierto un dato ineludible del panorama político: las dificultades inherentes al retorno de Ortiz al poder debido a su ceguera avanzada. Cierto es que fueron cuidadas las expresiones respecto a la irreversibilidad de su visión en los documentos aprobados, pero hacia octubre de 1940, el Presidente y su entorno familiar ya sabían por consejo de sus médicos que su ceguera era terminal y estaban al tanto de los riesgos que presentaba una eventual intervención quirúrgica ${ }^{54}$. Durante los meses siguientes, las apariciones públicas del Presidente enfermo mermaron en los principales medios gráficos, mientras que el clima político se reacomodó ante estos imponderables. La hipótesis de Félix Luna es que Ortiz no renunció después de la crisis en el Senado, dado que su sola presencia era una valla natural y "amenaza latente" para la política que imprimía el Vicepresidente en ejercicio, aunque a partir de mayo de 1941, la "muerte política" de Ortiz se adelantaba a su renuncia y desaparición física ${ }^{55}$.

Pero si Roberto Ortiz era un claro perdedor de la jugada del Senado, esta fue capitalizada por dos claros ganadores: el mismo Vicepresidente y el expresidente Agustín Justo. El vicepresidente Ramón Castillo logró reafirmar su poder al interior de la Concordancia y del gobierno al disipar el retorno real de Ortiz al poder, al mismo tiempo que comenzó a desplegar una política hacia el Ejército y en las provincias de creciente seducción y cooptación. El general Justo fue favorecido por la desactivación del retorno de Ortiz, dado que su imagen se acrecentaba hacia los radicales como la del único dirigente con posibilidad de devolverles el poder en elecciones limpias. Justo, a partir de allí, comenzó a desplegar un doble movimiento de negociación flexible -con los radicales y con sus aliados en las provincias-, pero, a su vez, con intervenciones públicas que buscaron ocupar un espacio "legalista" y claramente democrático a medida que se apagaba la llama del expresidente radical Marcelo Alvear y la de Roberto Ortiz. En los meses sucesivos, la lucha por el poder real entre Ramón Castillo y Agustín Justo se volvió esencial para el futuro de la Concordancia, de la oposición, y de las mismas instituciones de la república ${ }^{56}$.

En los meses siguientes, el Vicepresidente inició una firme y constante búsqueda de apoyos castrenses, sobre todo orientándose a los núcleos de oficialidad nacionalista, minoritarios, pero en crecimiento y lo suficientemente activos. Durante agosto y septiembre de ese año, y en ausencia del ministro de Guerra, Juan Tonazzi, aprobó una serie de medidas que levantaban los castigos a los oficiales conspirativos de principios de año, siendo beneficiados el general Benjamín Menéndez, el coronel Urbano de la Vega y el

\footnotetext{
La comisión produjo una declaración, una comunicación y un proyecto de ley que reglamentaba el art. 75 sobre la sucesión que recibió sanción del Senado, pero perdió estado legislativo en diputados. Véase, también, Ignacio López, "Un Presidente enfermo y una comisión investigadora. Prerrogativas senatoriales y el caso de inhabilidad presidencial durante la administración de Roberto M. Ortiz”, en Revista de historia del derecho, № 52, Buenos Aires, 2016, pp. 101-130.

${ }^{54}$ Luna, Ortiz..., op. cit., p. 220 y ss.

${ }^{55}$ Op. cit., p. 254.

${ }^{56}$ Privitellio, Agustín P. Justo..., op. cit., pp. 62-73.
} 
capitán Anacleto Llosa ${ }^{57}$. La información que proporciona Robert Potash, a través de los cables de la embajada estadounidense y algunas fuentes periodísticas, es que el mismo Ramón Castillo habría estado involucrado en un segundo intento golpista durante septiembre ${ }^{58}$. Otras fuentes allegadas al general Justo, reiteraron por esos meses un sonado triángulo conspirativo, compuesto por el mismo vicepresidente, el exgobernador bonaerense Manuel Fresco y el general Juan Bautista Molina; estos últimos con acceso directo $\mathrm{y}$ visitas recurrentes al despacho presidencial ${ }^{59}$.

Varios autores coinciden en afirmar una reunión central que celebró con militares con mando de tropa a principios de octubre, en la que este núcleo de oficiales presentó un memorial escrito con una serie de pedidos (o exigencias) al Poder Ejecutivo. Dicho ultimátum - que contaba con la aprobación de la mayoría de los comandantes de unidades en el área del Gran Buenos Aires- incluía al menos ocho puntos concretos: postergación indefinida de elecciones anunciadas en tres provincias intervenidas; disolución del Concejo Deliberante de Buenos Aires; retiro del general Agustín Justo de la actividad política; disolución del Congreso Nacional: proclamación del estado de sitio; clausura de varios periódicos; renuncia de los ministros de Guerra, Marina e Interior y mantenimiento de una política de rigurosa neutralidad ${ }^{60}$.

$\mathrm{Su}$ accionar en los meses venideros se fue orientando al cumplimiento de algunos puntos del ultimátum, aunque otros quedaron en suspenso y fueron descartados. Ese mismo octubre, decidió la clausura del Concejo Deliberante de la Capital Federal ${ }^{61}$. La noticia consternó a la opinión pública y, si bien los radicales -cuya mayoría gobernaba el Concejo- quedaron estupefactos ante la decisión, veían detrás de la medida o la "mano de Agustín Justo" o simplemente la "soberbia arrogancia" del Vicepresidente y debían esperarse otras medidas de fuerza destinadas a un gobierno con rasgos cada vez más autoritarios ${ }^{62}$.

En tanto, completó otras medidas para satisfacción de la corporación militar. Designó por esas fechas al coronel Manuel Savio a cargo de la recientemente creada Dirección General de Fabricaciones Militares; prohibió reuniones públicas organizadas por el grupo antifascista Acción Argentina y, por último, declaró el estado de sitio en diciembre de 1941, cuando se produjeron los ataques a Pearl Harbour sin plazos estimados ${ }^{63}$. Durante ese mes, además, el sector nacionalista se hizo con un puesto clave que tendría efectos políticos trascendentales en el futuro: Ramón Castillo sustituyó al jefe de policía

\footnotetext{
${ }^{57}$ Memorándum al General Justo, s/f, en Archivo General de la Nación, Fondo Agustín P. Justo, caja 106, doc. 90

${ }^{58}$ Potash, op. cit., pp. 227-229.

${ }^{59}$ Información del suboficial principal Fernández al General Justo, Buenos Aires, 23 de mayo de 1942, en Fondo Agustín P. Justo, caja 104, doc. 122 bis. También: Memorándum al General Justo, s/f, en Fondo Agustín P. Justo, caja 106, doc. 90.

${ }^{60}$ Potash, op. cit., p. 232; Schillizzi, op. cit., pp. 298-299; Félix Luna, Alvear, Buenos Aires, Sudamericana, 1958, p. 303.

${ }^{61}$ Decreto 102.843 PEN, en Archivo General de la Nación, Archivo Intermedio, Expedientes Generales, legajo 40-1941.

${ }^{62}$ Información de Ramón Cabezas al General Justo, Buenos Aires, 15 de octubre de 1941, en Fondo Agustín P. Justo, caja 103, doc. 130.

${ }^{63}$ Decreto 108.908 PEN, en Archivo Intermedio, Expedientes Generales, legajo 46-1941.
} 
de la Capital Federal designando al general nacionalista Domingo Martínez, en reemplazo del capitán Juan Rosas, declarado justista ${ }^{64}$.

Durante el primer semestre de 1942, su vínculo con parte de la oficialidad se vio consolidado. En marzo, coincidente con las elecciones legislativas, lanzó medidas más restrictivas con la prensa, los partidos políticos, los filmes y demás producciones artísticas y de divulgación; e, incluso, aprobó por decreto medidas más duras respecto a las transacciones en suelo argentino que podían hacer los extranjeros a través de la recién creada Sección de Vigilancia y Represión de Actividades Antiargentinas dentro de la órbita de la policía de la Capital Federal ${ }^{65}$.

Cuando hacia junio de 1942 se dio término a su interinato, haciéndose de la presidencia como titular, el vínculo con los nacionalistas se volvió aún más firme. El flamante Presidente promovió el ascenso de figuras clave del sector como el general Pedro Pablo Ramírez -futuro ministro de Guerra-, junto con otros generales ${ }^{66}$, y otorgó nuevas concesiones a las Fuerzas Armadas: el Senado aprobó el aumento de altos jefes del Ejército en una modificación de la Carta Orgánica, además de una batería de leyes que incrementaban el presupuesto en armamentos ${ }^{67}$.

Sin embargo, su estrecho lazo que lo unía con un sector de la oficialidad era solo una cara de la moneda. Desde el punto de vista estrictamente político-partidario, ese largo año que iba del segundo semestre de 1941 a junio de 1942 permitió advertir un avance de posiciones del Vicepresidente y el núcleo demócrata nacional en el Congreso y en las provincias. Más allá de los apoyos castrenses, su "mesura" y "prescindencia" lograron conquistar territorios y bancas. No solo mantuvo en funcionamiento el Congreso, lejos de las supuestas pretensiones de un núcleo entusiasta y amenazante de oficiales, sino que, además, convocó a elecciones en los distritos intervenidos tiempo antes por Roberto Ortiz. Entre noviembre de 1941 y mayo de 1942, los conservadores se hicieron con cuatro distritos (San Juan, Catamarca, Buenos Aires y Jujuy) antes controlados por comisionados federales o radicales, y triunfaron en las elecciones legislativas de marzo recuperando la mayoría en la Cámara Baja. Observada internamente la Concordancia, era cada vez más demócrata y menos antipersonalista (radical). Su orientación “exclusivista" fue un éxito.

En la mayoría de las provincias dos movimientos parecían notorios: por un lado, las fuerzas demócratas tendían a la cohesión y, si bien se oía la voz del general Agustín Justo, el vicepresidente Ramón Castillo emergía como un jugador central de articulación. Esta posición, más que a sus habilidades políticas innatas, se debía claramente a su posición presidencial, y a sus recursos políticos e institucionales. Así lo demuestran las gestiones del comité nacional del PDN que en una delegación presidida por el senador Gilberto Suárez Lago, presidente de la mesa directiva, viajó a las provincias de

\footnotetext{
${ }^{64}$ Potash, op. cit., p. 240.

${ }^{65}$ Karl Loewenstein, "Legislation against Subversive Activities in Argentina", in Harvard Law Review, vol. 56, No 8, Cambrigde, 1943, pp. 1261-1306.

${ }^{66}$ La Nación, Buenos Aires, 7 de junio de 1942. Algunas fuentes indican que Pedro P. Ramírez para esa fecha, tenía contactos recurrentes con Ramón Castillo y Miguel A. Culaciati, cfr: Información de Ramón Cabezas al General Justo, Buenos Aires, 7 de enero de 1942, en Fondo Agustín P. Justo, caja 104, doc. 3.

${ }^{67}$ La Nación, Buenos Aires, 10 de junio de 1942.
} 
Córdoba, San Juan y Catamarca para aglutinar fuerzas dispersas y tender a la unidad ${ }^{68}$. Por otro lado, las fuerzas provinciales antipersonalistas se dividían y dispersaban. En la mayoría de los distritos controlados por el oficialismo, y de cara a las renovaciones del Ejecutivo provincial, el radicalismo disidente (antiyrigoyenista, pero oficialista) tendía a fragmentarse -como lo había hecho históricamente-; incluso, en muchos distritos, las escisiones correspondían a pautas "legalistas" como sucedió en Santa Fe y Córdoba; mientras que en otros distritos dichas fragmentaciones respondían a pujas internas partidarias y disidencias de dirigentes, como en Catamarca y Buenos Aires ${ }^{69}$.

\section{FigURA 1}

El presidente Ramón Castillo ejerciendo su voto en marzo de 1942

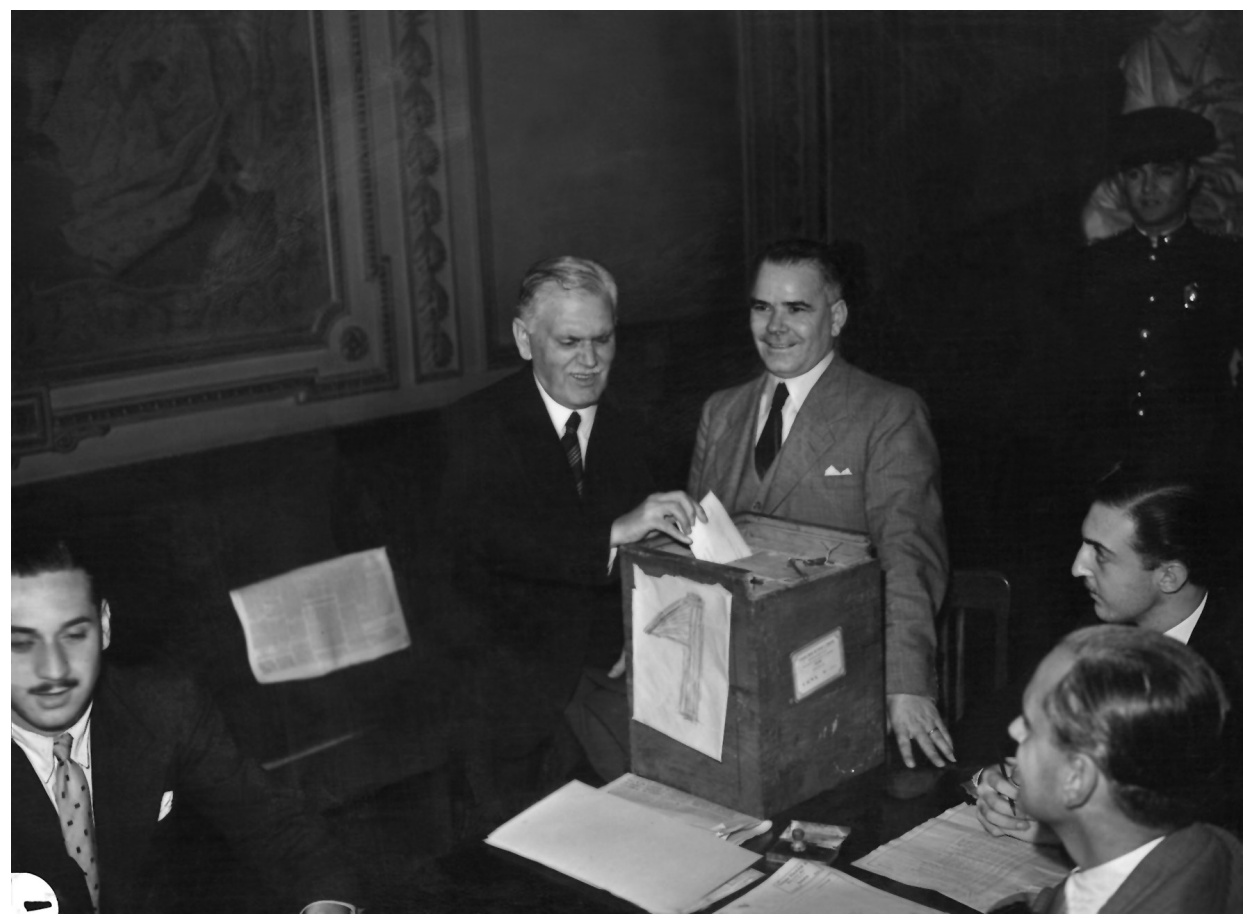

Cortesía del Archivo General de la Nación (Buenos Aires), Departamento de Documentos Fotográficos.

Los resultados promisorios de las elecciones de marzo de 1942, en las que los demócratas recuperaron terreno y recuperaron la mayoría parlamentaria perdida durante 1940, le permitieron al Vicepresidente plantear reformas de fondo en el sistema político. Desde

${ }^{68}$ La Nación, Buenos Aires, 31 de julio de 1941.

${ }^{69}$ Carta de Julio Figueroa a Alberto Figueroa, Catamarca, 11 de noviembre de 1941, en Fondo Agustín P. Justo, caja 103, doc. 187. También: Carta de Isaías Amado a Agustín Justo, Buenos Aires, 25 de septiembre de 1941, en Fondo Agustín P. Justo, caja 103, doc. 116; y Carta de Isaías Amado a Ramón Castillo, Buenos Aires, 6 de octubre de 1941, en Fondo Agustín P. Justo, caja 103, doc. 127. 
abril, el Poder Ejecutivo apuntó la necesidad de reformar algunas leyes de carácter político, sin mayores detalles ni precisiones. Luego trascendió a la prensa que el propósito de Ramón Castillo era presentar algunos proyectos de modificación de la ley electoral; sobre la organización de los partidos políticos; y sobre la ley orgánica municipal, especialmente en lo que se refería a la forma de constitución del Concejo Deliberante de la Capital Federal y que ya habían sido mencionadas en su mensaje al Congreso del año anterior ${ }^{70}$.

En febrero de 1943, el ministro del Interior presentó un anteproyecto de código político cuyo objetivo era contribuir a la sanción de normas que permitiesen perfeccionar prácticas cívicas y obtener una expresión de la "voluntad popular" más fiel. El documento - que no ingresó al Congreso para ser discutido- también buscaba "reglamentar la forma representativa de gobierno" adoptada por la Constitución nacional, pero no salía del paradigma sáenzpeñista y su universo de reformas. Excesivo en detalles, se colocó en un verdadero código que contemplaba fallos y omisiones de decretos anteriores que habían derivado en práctica viciada del sufragio: regulaba la constitución y organización de los partidos políticos, el acto electoral y sus procedimientos, y el proceso posterior de fiscalización y recuento ${ }^{71}$.

El anteproyecto constaba de varias partes. Una primera, doctrinaria, estaba condensada en los "fundamentos", una suerte de tratado político sobre el gobierno representativo donde se discernían nociones teóricas de "pueblo", sobre el "cuerpo electoral" y, luego, sobre los "partidos políticos", definidos como "asociaciones voluntarias" derivada de los naturales grupos de opinión en la sociedad y de su cristalización en la opinión pública. En este sentido, era fundamental que la legislación sobre los partidos políticos tendiese a la autenticidad en la representación: buscaba convertirlos en "escuela de democracia" 72 . Una segunda, el proyecto de ley propiamente dicho, otorgaba personería jurídica a los partidos, modificaba el régimen electoral aplicando el sistema de proporcionalidad a la minoría y quitaba a los analfabetos la capacidad de votar. Ramón Castillo, como el presidente Roque Sáenz Peña dos décadas antes, buscaba la sanción del proyecto de ley más ambicioso en materia política y electoral hasta el momento, para "imponer" y "modificar" las prácticas una vez sancionado: clara filiación con el saénzpeñismo más ortodoxo ${ }^{73}$.

Estas afirmaciones permiten complejizar lo que parte de la literatura académica ha visto como un hecho ineludible del accionar de Ramón Castillo: ciertamente el Vicepresidente tenía inclinaciones por un gobierno "fuerte" y no tan liberal, como lo demuestran sus medidas orientadas al "estado de excepción" permanente que vivió el país desde diciembre de 1941. Pero aún se movía en el universo democrático forjado dos décadas antes. Si Roberto Ortiz había representado la variante reformista de ese ethos promovido por el presidente Roque Sáenz Peña, Ramón Castillo encarnaba el saénzpeñismo más conservador.

${ }^{70}$ La Nación, Buenos Aires, 17 de abril de 1942.

${ }^{71}$ Ministerio del Interior, Anteproyecto de Código Político, Buenos Aires, Ministerio del Interior, 1943, pp. 1-13.

${ }^{72}$ Op. cit., pp. 11-13.

${ }^{73}$ Op. cit., pp. 75-197. 
EL EXCLUSIVISMO EN CLAVE PROVINCIAL.

El AVANCE DEMÓCRATA EN LAS PROVINCIAS DE JuJuy, CORRIENTES Y TuCumÁN

El primer semestre de 1942 modificó el panorama de la política nacional. El fallecimiento del líder del principal partido opositor y expresidente Marcelo T. de Alvear -durante marzo de 1942- y del Presidente de la República, Roberto M. Ortiz, durante julio, parecían haber despejado y simplificado el terreno para la contienda político-electoral que se avecinaba hacia el año próximo. Durante el segundo semestre de 1943 debían realizarse elecciones para la renovación del periodo constitucional 1944-1950. Durante el segundo semestre de 1942, el juego de poder en Argentina parecía gravitar en dos constelaciones de partidos y redes, con dos figuras centrales: por un lado, la candidatura virtual del general Agustín Justo, que recibía adhesiones de todos los núcleos antipersonalistas de las provincias (Santa Fe, Santiago del Estero, La Rioja, San Juan y Buenos Aires); de un grupo importante de dirigentes demócratas, entre los que estaban el núcleo bonaerense, cordobés y del Litoral; y de algunas dentro del universo radical del comité nacional -específicamente de la ciudad y provincia de Buenos Aires-. Agustín Justo comenzó a ser visto como el único posible candidato extrapartidario potable para esta pléyade compleja de apoyos, clave para agrupar fuerzas democráticas de cara a las definiciones de política exterior cada vez más acuciantes que se debían tomar en referencia al conflicto mundial.

Por el otro, el presidente Ramón Castillo y el núcleo duro demócrata, avanzaba a paso firme y definía nombres para la sucesión. El Presidente contaba no solo con toda la fuerza que le otorgaba naturalmente las prerrogativas del poder presidencial sino, además, con el apoyo de los partidos demócratas del resto de las provincias y de la tan mentada "coalición del Norte", un grupo de dirigentes demócratas de las provincias del Noroeste, clave por su número de electores en el Colegio para elegir Presidente y Vicepresidente.

Las posiciones políticas en las provincias y en algunos puestos centrales de las Fuerzas Armadas fueron los escenarios de ese enfrentamiento "frío" entre los dos contrincantes. Durante octubre y noviembre de 1942, Agustín Justo recibió una serie de golpes mortales: por un lado, Ramón Castillo intervino las provincias de Tucumán y Corrientes, cuyos gobiernos eran aliados potenciales para la ecuación justista en el Colegio Electoral. Por otro lado, el Presidente desplazó al último resorte el poder del ex Presidente en el Ejército: el general Juan Tonazzi, ministro de Guerra -y fiel justista-, renunció a su cargo y fue reemplazado por Pedro Ramírez, el ascendente General del núcleo nacionalista ${ }^{74}$.

En enero de 1942, el Presidente había aprovechado un conflicto local entre el Gobernador y la legislatura, y arrebató la provincia de Jujuy a los radicales opositores, que, casualmente, también tendían lazos con el expresidente Agustín Justo. Meses después, en septiembre, el presidente Ramón Castillo emprendió una larga gira por las provincias del norte argentino, que tendría importante repercusión política. A lo largo de un mes

\footnotetext{
${ }^{74}$ Pedro Ramírez, que formaba parte del viejo núcleo de militares uriburistas, fue una figura clave en el ascenso de ese sector durante el gobierno de Ramón Castillo. También su participación en la insurrección militar del 4 de junio (o su complicidad) fueron centrales para el éxito del golpe, véase Potash, op. cit., pp. 206-261.
} 
entero visitó Corrientes, Santa Fe, Salta, Santiago del Estero, Tucumán, Catamarca y La Rioja, además de los territorios nacionales de Chaco y Formosa ${ }^{75}$.

Pronto, el Presidente analizó la situación en dos distritos que presentaron tensiones y conflictos institucionales. Corrientes, que había presentado tensiones a lo largo de varios años por las denuncias de opositores, fue intervenida en octubre de $1942^{76}$. Tucumán, envuelta en un impasse por diputas en la conformación del Colegio Electoral, que debía ungir a un nuevo gobernador, fue también supeditada a la órbita del gobierno nacional un mes después. Una observación más perspicaz, permite recordar que ambos distritos eran clave en los planes del expresidente Agustín Justo para un eventual cálculo electoral. Su influencia, en ambos casos, fue seriamente coartada por Ramón Castillo.

Los dos distritos permanecieron intervenidos durante los primeros meses de $1943 \mathrm{y}$ se volvieron centrales para asegurar una sucesión ordenada del próximo Presidente demócrata. Castillo, en tanto, ordenó la convocatoria a elecciones a gobernador en ambos casos para agosto de 1943, prevista un mes antes de las presidenciales a fin de tener la maquinaria partidaria aceitada para el desafío mayor ${ }^{77}$. Sin embargo, la insurrección de junio impidió que dichos procesos electorales se llevasen a cabo y ambas provincias continuaron intervenidas por el nuevo gobierno de facto.

\section{La primera embestida:}

\section{La intervención a la provincia de Jujuy (enero de 1942)}

La provincia de Jujuy representó el primer paso de un modus operandi del castillismo a inicios de 1942: la intervención federal. Ramón Castillo normalizó las autoridades de tres distritos que habían sido intervenidos por Roberto Ortiz (Buenos Aires, Catamarca y San Juan), y quedaron nuevamente bajo la órbita demócrata. Esta estrategia posibilitó que el Vicepresidente pudiese ensayar en algunas provincias, bajo control opositor (o envueltas en tensiones institucionales), la posibilidad de intervenir directamente y abandonar la retórica de la defensa de las autonomías ${ }^{78}$. Al igual que Roberto Ortiz, Ramón Castillo comprendió pronto los beneficios de enviar una misión federal en distritos problemáticos en ese particular contexto: control territorial de las jurisdicciones intervenidas; promoción de alianzas con las agrupaciones locales, en este caso, inflar a las fuerzas demócratas en detrimento de radicales (tanto antipersonalistas como del comité nacional) y sanción a los gobernadores díscolos (u opositores) $)^{79}$.

\footnotetext{
${ }^{75}$ La Nación, Buenos Aires, 2 de septiembre de 1942.

${ }^{76}$ Ignacio López, “Aliados pero fraudulentos. Las prácticas políticas en Santa Fe, Mendoza y Corrientes durante el bienio de Roberto M. Ortiz (1938-1940)", en Revista de Historia Americana y Argentina, vol. 51, $\mathrm{N}^{\mathrm{o}}$ 1, Mendoza, pp. 103-130.

${ }^{77}$ La Nación, Buenos Aires, 21 de mayo de 1943.

${ }^{78}$ Sobre la utilización de las intervenciones federales, véanse Natalio Botana, El orden conservador. La política argentina entre 1880 y 1916, Buenos Aires, Sudamericana, 1977; Ana María Mustapic, "Conflictos institucionales durante el primer gobierno radical: 1916-1922”, en Desarrollo Económico, vol. 24, No 93, Buenos Aires, 1984, pp. 85-108.

${ }^{79}$ Natalio Botana, "Prólogo", en Ernesto Calvo y Juan Manuel Abal Medina (h) (eds.), El federalismo electoral argentino: sobrerrepresentación, reforma política y gobierno dividido en la Argentina, Buenos Aires, Eudeba, 2001, pp. 13-20.
} 
Sin embargo, el modo de intervención de Ramón Castillo, a diferencia del de Roberto Ortiz, presentaba tres innovaciones claras: primero, el Vicepresidente optó por misiones federales quirúrgicas o express, como lo demuestran no solo el rápido llamado a elecciones de los tres distritos intervenidos por Roberto Ortiz sino, también, por la veloz convocatoria en las provincias que él mismo intervino -esto era importante para el discurso del Vicepresidente, que decía estar preocupado por la defensa de las autonomías provinciales- ${ }^{80}$; segundo, el motivo de intervención no estuvo vinculado a procesos electorales fraudulentos, sino a verdaderos conflictos institucionales locales como lo demostró su accionar en Jujuy, pero también en Tucumán (en el marco de un impasse producto de una elección) y en Corrientes, y tercero, nominó a eminentes demócratas o resonantes nacionalistas para los cargos de comisionados, que se colocaron en verdaderos operadores políticos y gestores de las instrucciones del gobierno federal a su cargo.

El caso jujeño merece consideraciones detalladas, ya que significó el primer paso de un avance demócrata en una provincia controlada por el radicalismo opositor ${ }^{81}$. Los radicales, mediante la conformación de un frente radical - que unía a radicales del comité nacional y antipersonalistas-, y con los auspicios de la política presidencial de Roberto Ortiz, se hicieron con el control de la provincia en marzo de $1940^{82}$. Un año después del triunfo, el antipersonalista Julio Palmeyro le relataba al general Agustín Justo que el gobierno del radical Raúl Bertrés solo se sostenía gracias al apoyo mancomunado de estas fuerzas radicales; y que de "producirse fracturas en la coalición" solo la policía podría sostener al gobierno ${ }^{83}$.

En mayo de 1941 comenzaron a complicarse las relaciones entre el Gobernador radical y el bloque opositor del Partido Popular - conservadores de la provincia- en la legislatura. Los legisladores populares denunciaron ante el ministro del Interior el estado de "desorden administrativo e inmoralidad política" que vivía la provincia solicitando la "intervención federal amplia". Había, además, serios "límites a la libertad de prensa" como lo demostraban el proceso de encarcelamiento del director del diario El Día, las agresiones a corresponsales del periódico La Nación y detenciones arbitrarias de los directores y periodistas de los periódicos La Opinión, La Voz del Norte y La Provincia ${ }^{84}$.

El gobernador Raúl Bertrés dirigió varios telegramas durante esas semanas de mayo al ministro del Interior. En la primera de esas misivas acusaba al bloque popular de no concurrir a la Asamblea Legislativa e imposibilitar la conformación de la mesa directiva, dilatando el inicio de sesiones ordinarias. Ante tal situación, solicitaba al ministro Miguel A. Culaciati la intervención a la provincia, pero "limitada" solo a la legislatura por medio de una ley del Congreso ${ }^{85}$.

${ }^{80}$ Ramón S. Castillo, Mensaje del Vicepresidente de la Nación en ejercicio del Poder Ejecutivo al inaugurar el período ordinario de Sesiones del H. Congreso Nacional, Buenos Aires, Imprenta del Congreso, 1942, pp. 10-11.

${ }^{81}$ Para el caso jujeño cfr. Kindgard, op. cit., pp. 12-45.

${ }^{82}$ Ignacio López, Camino a la democratización. Consideraciones sobre la politica reformista de Roberto M. Ortiz, tesis de maestría en Historia, Buenos Aires, Universidad Torcuato Di Tella, 2013, pp. 144-169.

${ }^{83}$ Julio Palmeyro a Agustín Justo, Jujuy, 28 de enero de 1941, en Fondo Agustín P. Justo, caja 103, doc. 9.

${ }^{84}$ Sres. Roberto Undiano, Roberto Bidondo, Oscar Rebaudi Basavilbaso, Carlos Bárcena, Atanasio Ojeda, Edison Wiaggo, Mamerto Zalazar, Carlos Aparicio, Juan Roqués y Alberto Caraciola a Miguel A. Culaciati, Jujuy, 4 de mayo de 1941, publicado en La Nación, Buenos Aires, 4 de mayo de 1941.

${ }^{85}$ Raúl Bertrés a Miguel A. Culaciati, Jujuy, 5 de mayo de 1941, publicado en La Nación, Buenos Aires, 6 de mayo de 1941. 
En tanto, los legisladores populares no daban tregua al gobierno radical. En los días sucesivos una lluvia de telegramas llegó al Ministerio del Interior con graves denuncias de "policías armados" y "camiones, autos y coches que patrullaban para atemorizar a los ciudadanos" ".6 Las denuncias fueron incrementándose debido a una intensa campaña que orquestaba el senador jujeño Plinio Zabala. Este le escribió al ministro Miguel A. Culaciati describiendo que en Jujuy se vivía un estado de "explosión de barbarie". Su sentencia era que el gobierno jujeño "probablemente desesperado por su inestabilidad", extremase las medidas de violencia porque solo podía sostenerse por el "terror"

La situación llegó a su punto más álgido cuando el senador Plinio Zabala y el diputado provincial Oscar Rebaudi Basavilbaso denunciaron un atentado en el domicilio de este último perpetrado por personal policial provincial. Una fuerte movilización de estudiantes del Colegio Nacional fue el corolario de la exacerbación de los ánimos. El Gobernador negó los hechos de forma terminante ${ }^{88}$. Una entrevista personal del Gobernador con el Vicepresidente a fines de mayo posiblemente sirvió para dilatar los tiempos, y dar mayores oportunidades al Gobernador para solucionar los graves problemas de inestabilidad. Sin embargo, Ramón Castillo prometió enviar al Congreso de la Nación los antecedentes del caso a fin de que evalúe la situación institucional ${ }^{89}$.

Días después, Raúl Bertrés se apresuró en buscar apoyos en la Cámara de Diputados. Allí dirigió una serie de telegramas al presidente de la Comisión de Negocios Constitucionales, el radical Emilio Ravignani, a fin de dar cuenta de los hechos que vivía la provincia $^{90}$, pero, a su vez, para que se formulase un despacho en el seno de esa comisión a fin de evitar que la oposición insistiese ante el Poder Ejecutivo para conseguir que el problema sea resuelto mediante el envío de una intervención, cuestión que no sucedería si la Cámara procediese antes del fin de las sesiones ${ }^{91}$.

Hacia julio, la misión demócrata encabezada por el senador Gilberto Suárez Lago también llegó a Jujuy y logró con éxito la fusión del Partido Popular con el Partido Demócrata Nacional. El senador Herminio Arrieta -clave en la comisión senatorial sobre el estado de salud del presidente Roberto Ortiz- fue también central para lograr el acercamiento de las dos agrupaciones con el objetivo de cerrar filas en la provincia del norte y presentar una oposición local más cohesionada frente al radicalismo oficialista ${ }^{92}$.

En octubre, el vicegobernador Alberto Pasquini denunció ante el Gobernador la inminencia de un movimiento cívico-militar que encabezarían los populares para destituir al gobierno radical ${ }^{93}$. Al mismo tiempo, le señalaba al general Agustín Justo la existencia de dos corrientes nítidas del antipersonalismo jujeño. Una que buscaba la interven-

\footnotetext{
${ }^{86}$ Raúl Bertrés a Ramón Castillo, Jujuy, 9 de mayo de 1941, publicado en La Nación, Buenos Aires, 10 de mayo de 1941.

${ }^{87}$ Conferencia telefónica entre Plinio Zabala y Miguel A. Culaciati, Jujuy, 12 de mayo de 1941, reproducido en La Nación, Buenos Aires, 13 de mayo de 1941.

${ }^{88}$ La Nación, Buenos Aires, 20 de mayo de 1941.

89 “Se entrevistó con el Dr. Castillo el gobernador jujeño", en La Nación, Buenos Aires, 27 de mayo de 1941,

${ }^{90}$ Raúl Bertrés a Emilio Ravignani, Jujuy, 24 de junio de 1941, en Fondo Agustín P. Justo, caja 103, docs. 78-79-85.

${ }^{91}$ Raúl Bertrés a Emilio Ravignani, Jujuy, 1 de agosto 1941, en Fondo Agustín P. Justo, caja 103, doc. 94.

${ }^{92}$ La Nación, Buenos Aires, 22 de julio de 1941.

${ }^{93}$ Alberto Pasquini a Raúl Bertrés, Jujuy, 18 de octubre de 1941, en Fondo Agustín P. Justo, caja 103, doc. 134.
} 
ción a la provincia y que era minoritaria (antiJusto), y la mayoritaria que respondía al liderazgo del ex Presidente, por intermedio del mismo Vicegobernador, quien también exhortó a Agustín Justo sobre la necesidad de unir fuerzas con el radicalismo personalista, liderado por el exgobernador Miguel Ángel Tanco, dividiéndose en partes iguales los cargos legislativos provinciales y nacionales de cara a las elecciones legislativas de marzo de $1942^{94}$.

Sin embargo, en enero estalló el conflicto latente, esta vez promovido por el Poder Ejecutivo Nacional. Luego de la normalización exitosa de tres provincias con triunfos demócratas resonantes, Ramón Castillo evaluó la situación jujeña, mientras estaba en receso el Congreso Nacional. Fue así como, a mediados de enero de 1942, el Presidente decretó el envío de una misión federal a la provincia del norte nombrando como comisionado al jurista Nicolás González Iramain -hermano de Héctor, senador riojano y eminente socialista independiente-. Sin embargo, continuó el mismo Jefe de Policía por intermediación de Agustín Justo ${ }^{95}$. El decreto de intervención enumeraba los problemas institucionales y el estado de "intranquilidad y exaltación pública"96. En sus instrucciones al interventor, el ministro del Interior Miguel A. Culaciati ordenó la disolución de los poderes Ejecutivo y Legislativo -en contra de lo pedido por Raúl Bertrés, que buscaba una intervención "limitada" a la Legislatura-; y pedía colocar a la provincia en condiciones de realizar las próximas elecciones a diputados nacionales que ocurrirían en el mes de marzo y demás disposiciones de tenor administrativo ${ }^{97}$. El resultado de la intervención fue que en las elecciones legislativas de marzo triunfó con facilidad la fórmula de los demócratas nacionales llevándose los dos diputados en juego, en un ambiente de tranquilidad y corrección electoral ${ }^{98}$.

El general Agustín Justo, en ese momento, se mostró favorable a la convocatoria rápida a elecciones para gobernador, una vez sucedidas las elecciones de marzo ${ }^{99}$. Un mes después, y ante la convocatoria a elecciones a gobernador a fines de mayo, el exvicegobernador Alberto Pasquini daba sus impresiones al teniente coronel Ambal que todo estaba encarrillado para que triunfasen los conservadores. Para el ex Vicegobernador, estaban las condiciones dadas para que se unan todos los radicales en una candidatura como la del octogenario dirigente Benjamín Villafañe ${ }^{100}$. En ese ambiente, los antipersonalistas solicitaron la postergación de las elecciones por unos ocho meses con el objetivo de reorganizarse ${ }^{101}$.

${ }^{94}$ Alberto Pasquini a Agustín Justo, Jujuy, 30 de diciembre de 1941, en Fondo Agustín P. Justo, caja 103, doc. 320 .

${ }^{95}$ Aníbal Velázquez a Agustín Justo, Jujuy, 24 de enero de 1942, en Fondo Agustín P. Justo, caja 104, doc. 18.

${ }^{96}$ Decreto 111.660, 21 de enero de 1942, en Archivo Intermedio, Expedientes Generales, legajo 4-1942.

${ }^{97}$ La Nación, Buenos Aires, 29 de enero de 1942.

${ }^{98}$ Herminio Arrieta a Agustín Justo, Jujuy, 3 de marzo de 1942, en Fondo Agustín P. Justo, caja 104, doc. 56.

${ }^{99}$ Agustín Justo a Miguel Rojas, Mar del Plata, 10 de marzo de 1942, en Fondo Agustín P. Justo, caja 133, doc. 4 .

${ }^{100}$ Alberto Pasquini al teniente coronel Ambal, Jujuy, 3 de abril de 1942, en Fondo Agustín P. Justo, caja 104, doc. 88 .

${ }^{101}$ Salvador Espinosa (UCRA) a Miguel A. Culaciati, Jujuy, 10 de marzo de 1942, en Archivo Intermedio, Expedientes Generales, legajo 4-1942. 
A principios de mayo se produjo la estrepitosa renuncia del interventor jujeño Nicolás González Iramain ${ }^{102}$. En su carta de renuncia consideraba que su deber era presidir "comicios libres" además de "impedir" que "incapaces o delincuentes" se apoderasen del gobierno. En el fondo, el interventor planteaba una dura crítica a la clase dirigente jujeña y consideraba difícil la solución que se pretendía dar al pleito institucional de la provincia mediante los mismos métodos políticos ${ }^{103}$. En su reemplazo fue nombrado el demócrata catamarqueño Francisco Galíndez quien colocó a la provincia en condiciones para elegir autoridades según los deseos del Poder Ejecutivo ${ }^{104}$. En vísperas de las elecciones, la UCR lanzó un furioso manifiesto donde declaraba la abstención para las próximas elecciones a gobernador. Resaltaba la actitud legalista del presidente Roberto Ortiz, pero también la labor del exinterventor que había denunciado los hechos delictuosos, cometidos, sobre todo, bajo la órbita del ministro de Gobierno, Guillermo Cano ${ }^{105}$.

Cuando a fines de mayo se realizaron elecciones para gobernador, vicegobernador, diputados de la legislatura y concejales solo se concurrieron el Partido Demócrata Nacional y el Partido Socialista. El acto no presentó ninguna incorrección ante el control de las fuerzas policiales. Por último, triunfó por amplio margen el PDN con la fórmula Penelón de la Quintana y René Bustamente ${ }^{106}$. En los primeros días de junio, se completó la transición de autoridades que confirmó a Jujuy (nuevamente) bajo la gravitación de las fuerzas concordancistas, y con clara hegemonía demócrata, de acuerdo con los deseos del vicepresidente Ramón Castillo.

\section{La esperada intervención a Corrientes (octubre de 1942)}

Corrientes era una provincia dominada por la Concordancia desde 1932. Una coalición de autonomistas y radicales antipersonalistas había mantenido los resortes gubernamentales por una década. La oposición radical (del comité nacional) y liberal había denunciado recurrentemente los abusos institucionales del oficialismo, y los pedidos de intervención federal, se habían acelerado durante el bienio de Ortiz ${ }^{107}$. La muerte del senador correntino Juan Ramón Vidal durante septiembre de 1940 -líder del autonomismo- había producido una escisión en los demócratas de la provincia. Una fracción se separó del partido en desacuerdo con la política aliancista de los demócratas/autonomistas y antipersonalistas; y otro grupo mantuvo la alianza con el antipersonalismo, agrupación a la que pertenecía el gobernador Pedro Numa Soto, muy allegado al presidente Ortiz ${ }^{108}$.

${ }^{102}$ Expedientes 16.852, 16.853, 16.929, 17.657, en Archivo Intermedio..., op. cit.

103 "La renuncia del interventor en Jujuy", en La Nación, Buenos Aires, 2 de mayo de 1942.

${ }^{104}$ Decreto 118.883, en Archivo Intermedio, Expedientes Generales, legajo 4-1942.

105 Unión Cívica Radical al pueblo de la Provincia, Jujuy, mayo de 1942, en Archivo Intermedio, Expedientes Generales, legajo 4-1942, E. 21.566.

${ }^{106}$ La Nación, Buenos Aires, 1 de junio de 1942.

${ }^{107}$ Sobre la política en la provincia de Corrientes, cfr: Solís, Liderazgo y política..., op. cit. y Solís, La cultura política..., op. cit. También "Autonomistas, liberales y radicales en Corrientes. Actores, prácticas e identidades políticas en conflicto (1909-1930)", en Prohistoria, año XIII, No 13, Rosario, 2009, pp. 31-50. Sobre la década de 1930: Ricardo Harvey, Historia politica contemporánea de la provincia de Corrientes 1936-1941, Corrientes, Moglia Ediciones, 2008 y López, “Aliados pero fraudulentos...”, op. cit., pp. 103-130.

${ }^{108}$ La Nación, Buenos Aires, 21 de noviembre de 1941. 
La separación de esos dos grupos demócratas ahondó la crisis institucional local. De hecho, el grupo disidente se adhirió a las solicitudes de intervención federal formuladas por los partidos opositores (radicales del comité nacional y liberales) que desde hacía tiempo reclamaban al gobierno nacional. Se promovió un nuevo entendimiento entre autonomistas disidentes y liberales, ambos partidos fundamentales en la estabilidad del sistema político local desde antes de 1930, que llevaron a una nueva fusión autonomista-liberal.

El dirigente Ginés Lubary daba cuenta a un destinatario anónimo de la situación provincial y consideraba también que la muerte de Juan R. Vidal había hecho desmedida la ambición de sus partidarios. Posiblemente se estaba dando en el ámbito local, una reconfiguración encarnizada de los liderazgos partidarios. Hacia fines de ese año 1940, la situación política nacional indicaba la imposibilidad de intervenir la provincia, aunque "había que ganar tiempo" y buscar la "unidad partidaria" dentro del autonomismo para evitar peligros mayores. Sin embargo, la "obstinación" de algunos dirigentes, provocaría la intervención y muchos lo daban "como un hecho para mediados del próximo año"109.

Durante fines de año 1941, una nueva agrupación, la Unión Popular de Corrientes -que se decía una fuerza "cívica" y no política- presentó un nuevo memorial sobre el estado general de la provincia ${ }^{110}$. Posteriormente se presentó a las elecciones de renovación de la legislatura local de marzo de 1942, criticando la abstención opositora, pero denunció irregularidades graves una vez sucedidos los comicios ${ }^{111}$. Allí abandonó la prédica "autonómica" y mediante un giro brusco fue una de las agrupaciones locales más solícitas en pedir la "intervención federal amplia" ante el vicepresidente Ramón Castillo ${ }^{112}$.

Hacia mayo de 1942, el dirigente Alberto Núñez Lozano confirmaba algunos elementos centrales del panorama político provincial. En una misiva a Agustín Justo le solicitaba con énfasis que alejase "al profesor Miranda Contreras -líder de la Unión Popular- de la provincia" por sus pedidos recurrentes de intervención y su cercanía a Ramón Castillo (había sido recibido en audiencia por este unos pocos días antes). Posiblemente algún cargo en la Capital Federal o la provincia sería efectivo para eliminar su acción disruptiva contra el gobierno provincial de Numa Soto. Alberto Núñez estimaba con acierto que el "profesor" había sido eficaz en monopolizar a la oposición, pero que los planes de Miranda - lograr la intervención- serían "funestos" para la Concordancia. De lograr su cometido "se perderían la mayoría de los electores en el Colegio" para llevar a la presidencia a Agustín Justo, cuya candidatura era sostenida por las fuerzas oficialistas de la provincia. La "coalición popular" que crearía Miranda sería contraria a los intereses del General y favorable a Ramón Castillo ${ }^{113}$.

\footnotetext{
${ }^{109}$ Ginés Lubary a destinatario desconocido, Buenos Aires, 26 de mayo de 1941, en Fondo Agustín P. Justo, caja 103, doc. 67.

${ }^{110}$ Unión Popular de Corrientes, diciembre de 1941, en Archivo Intermedio, Expedientes Generales, legajo 24-1942, E. 21.587.

${ }^{111}$ La Voz de Corrientes, Corrientes, 28 de marzo de 1942.

${ }^{112}$ Proclama de la Unión Popular de Corrientes, Corrientes, 1 de abril de 1942, en Archivo Intermedio, Expedientes Generales, legajo 24-1942, E. 21.587.

113 Alberto Núñez Lozano a Agustín Justo, Corrientes, 24 de mayo de 1942, en Fondo Agustín P. Justo, caja 104, doc. 123.
} 
Lo cierto es que la Unión Popular y Contreras Miranda eran los más ávidos orquestadores de una campaña "antiJusto" en la provincia. En una nota en su diario La Voz de Corrientes que titulaba "El General Justo no será presidente de la República", la agrupación política atacaba los lineamientos en materia exterior que propiciaba el ex Presidente. Una de las principales razones de oposición del grupo y "por las que no sería presidente" eran los "coqueteos belicistas" del General ante el conflicto mundial. El haber ofrecido a Brasil sus servicios técnicos como general honorario -había sido condecorado por Getulio Vargas- era una "imprudencia” y lo colocaba por fuera de la Constitución ${ }^{114}$.

A fines de septiembre de 1942, trascendió a la prensa que el Ministerio del Interior estaba analizando uno de los tantos informes que la oposición correntina había presentado y la intervención federal sería inminente. En su último viaje, el Presidente había visitado la provincia, y posiblemente, haya madurado allí la idea definitiva de enviar una misión federal ${ }^{115}$. La revista Newsweek veía en esa intervención un "golpe a las ambiciones presidenciales de Justo", y en una serie de medidas restrictivas a la prensa sobre noticias para el exterior, la imposición de una "más estrecha dictadura"

En menos de una semana salió el decreto de intervención del despacho presidencial y se nombró como comisionado al demócrata Francisco Galíndez, que había logrado recientemente la normalización en la provincia de Jujuy. La misión Castillo no iba "ni a favor ni en contra de ninguno de los grupos políticos de la provincia" sino que simplemente se dirigía a "organizar los servicios públicos para garantizar ampliamente los derechos ciudadanos"117. El decreto daba cuenta de que hacían "más de tres años" que llegaban al Poder Ejecutivo denuncias sobre la situación social y política de la provincia y que había un proyecto de ley de intervención en el Congreso que no había sido sancionado. Corrientes, según el decreto, se encontraba en un estado propicio para "el predominio de inferiores móviles políticos sobre los derechos ciudadanos" ${ }^{\prime 18}$.

El gobernador Pedro Numa Soto le contestó al ministro del Interior en una serie de documentos defensivos ${ }^{119}$. Un grupo de senadores provinciales, en tanto, defendieron al gobierno local y al funcionamiento del cuerpo legislativo. Consideraba que las informaciones que contenía el decreto de intervención eran "desleales" y que había en Corrientes un "juego armónico de funciones" entre los tres poderes. No existía ni "supeditación" ni "sistemático consentimiento al Poder Ejecutivo de la provincia" como se argüía en el decreto ${ }^{120}$. El Gobernador aprovechó su último movimiento para montar una gran escena dramática: sancionó un decreto en el que consideraba la intervención como

${ }^{114}$ La Voz de Corrientes, Corrientes, 28 de septiembre de 1942.

${ }^{115}$ La Nación, Buenos Aires, 30 de septiembre de 1942.

116 "El general Justo pierde el control de Corrientes" (traducción), en Newsweek, New York, october 19, 1942, Fondo Agustín P. Justo, caja 104, doc. 327.

${ }^{117}$ La Nación, Buenos Aires, 6 de octubre de 1942.

${ }^{118}$ Decreto No 132.312 PEN, 5 de octubre de 1942, en Archivo Intermedio, Expedientes Generales, legajo 24-1942, E. 40.630.

${ }^{119}$ Pedro Numa Soto a Miguel A. Culaciati, Corrientes, 5 de octubre de 1942, en Archivo Intermedio, Expedientes Generales, legajo 24-1942, E. 41.192.

${ }^{120}$ Juan Figueredo y otros (Senado de la provincia) a Miguel A. Culaciati, Corrientes, 6 de octubre de 1942, en Archivo Intermedio, Expedientes Generales, legajo 24-1942, E. 41.301. 
un "acto de avasallamiento sorpresivo" sin "ninguna causa de carácter institucional" y acusó al Presidente de contener en su gabinete a elementos "fascistas"

Pero, además, la fractura fue visible en la coalición gobernante que unía a demócratas y radicales antipersonalistas. El comité central del antipersonalismo de Corrientes no tardó en solidarizarse con el Gobernador, distanciarse de los demócratas y reafirmar su orientación democrática y de repudio a todo régimen "totalitario y exótico"122. Sin embargo, los demócratas nacionales expresaron su adhesión a la política de Ramón Castillo y llamaron a una "unidad indestructible" para recuperar la provincia ${ }^{123}$.

El interventor Francisco Galíndez a partir de octubre cumplió su cometido político y preparó la provincia para las elecciones que se celebrarían en agosto. Con ese objetivo se garantizaría que los electores correntinos estuviesen, para las próximas elecciones presidenciales, alineados con los deseos del presidente Ramón Castillo.

La tercera (no) es la vencida:

La intervención federal a Tucumán (noviembre de 1942)

Desde el año 1934 los radicales controlaron la gobernación de la provincia de Tucumán. El concurrencismo tucumano fue uno de los radicalismos competitivos de la década de 1930, y a diferencia de los lineamientos abstencionistas del comité nacional, decidió tempranamente lanzarse a la arena electoral. Hacia mediados de la década, ganó el distrito, y su dirigencia, según investigaciones recientes, fue hábil en el alineamiento político con el gobierno de Agustín Justo ${ }^{124}$.

Mucho antes de que se sucediesen los episodios que derivaron en la intervención a la provincia, el inspector general de policía provincial, Federico Donadío, le manifestaba al expresidente Agustín Justo que en la próxima presidencia sería clave el distrito para garantizar electores en favor de su candidatura ${ }^{125}$.

Durante 1941 se llevaron a cabo elecciones locales que encontraron a los demócratas divididos en algunas secciones, pero también a los radicales fraccionados en diversas corrientes: el Frente Popular, los liguistas y los agrarios. Como era usual en política tucumana, según un observador anónimo, mientras las fuerzas demócratas se movían "tres semanas antes" de las elecciones, las facciones radicales lo hacían "desde hacía meses"

${ }^{121}$ Suplemento La Nueva Época, Corrientes, 5 de octubre de 1942, en Archivo Intermedio, Expedientes Generales, legajo 24-1942, E. 53.775.

${ }^{122}$ UCR Antipersonalista de Corrientes, Corrientes, 20 de octubre de 1942, en Fondo Agustín P. Justo, caja 104, doc. 333.

${ }^{123}$ Manifiesto PDN de Corrientes, Corrientes, 10 de noviembre de 1942, en Fondo Agustín P. Justo, caja 104, doc. 358.

${ }^{124}$ Piñeiro, "Los radicales antipersonalistas...", op. cit., pp. 164-165 y 199-200. Sobre política tucumana durante la década de 1930, cfr. María Fernández de Ullivarri, Trabajadores, sindicatos y política en Tucumán. 1930-1943, tesis de doctorado en Historia, Buenos Aires, Universidad de Buenos Aires Facultad de Filosofía y Letras, 2010. También Graciana Parra, "Blancos, demócratas y radicales en la encrucijada de los años treinta. El impuesto adicional al azúcar, Tucumán 1932-1934”, en Travesía, № 13, Tucumán, 2011, pp. 127-162 y "Los demócratas tucumanos...", op. cit., pp. 85-106.

${ }^{125}$ Federico Donadío a Agustín Justo, Tucumán, 16 de abril de 1941, en Fondo Agustín P. Justo, caja 103, doc. 54 . 
lo que garantizaba sus cómodos triunfos electorales ${ }^{126}$. A mediados de julio, la visita del senador Gilberto Suárez Lago buscó unificar las filas demócratas al momento en que estas se desprendían en la conformación de un nuevo partido (Cívico Popular) con destacados conservadores locales como Juan Carlos Cossio o Luis Nougués ${ }^{127}$. La intervención del presidente del comité nacional del PDN logró contener la fuga partidaria, y tiempo después los demócratas volvieron a unir voluntades.

En marzo de 1942, el radicalismo concurrencista fue derrotado en las urnas. La buena performance demócrata que se quedó con la mayoría de los legisladores llevó a que los diversos sectores radicales propiciaran la reunificación de fuerzas en un frente común. Fue así como la UCR concurrencista, la UCR tradicionalista (del exgobernador radical Miguel Campero) y la UCR Frente Popular, decidieron unirse y presentar la UCR Alianza Partidaria. Este frente "panradical" levantó la postulación aglutinante de Miguel Campero - muy cercano a Justo-. Sin embargo, los radicales del comité nacional decidieron postular a Roque Aragón y no concurrir conjuntamente en ese frente ${ }^{128}$.

Algunas informaciones posteriores, hacían constar que la UCR CN presentaría candidatos propios a la elección a fin de "obstaculizar" la candidatura del exgobernador Miguel Campero ${ }^{129}$. En tanto, este escribió a Agustín Justo para solicitar su apoyo, que sería fundamental en la contienda ${ }^{130}$. Todo indica que el General financió a través del senador nacional Manuel García Fernández la candidatura del ex Gobernador con aportes de cerca de los treinta mil pesos, lo que demuestra lo fundamental que era la provincia en los planes presidenciales del General ${ }^{131}$. En los círculos radicales era sabido que Miguel Campero trabajaba hacía meses para una segunda presidencia de Agustín Justo ${ }^{132}$.

Por otro lado, los demócratas (reunificados) presentaron a Adolfo Piossek -en ese momento rector de la Universidad Nacional de Tucumán- y los socialistas fueron en la boleta con el reformista Julio V. González. La agrupación Bandera Blanca no presentó candidatos propios, aunque apoyó de forma extraoficial al candidato conservador y concurrió en algunos distritos para cargos menores ${ }^{133}$. Su candidatura contó, además, con el aval directo de todo el arco conservador de la provincia -inclusive del Partido Cívico Popular-y de la dirigencia nacional del $\mathrm{PDN}^{134}$.

${ }^{126}$ Informe sobre la situación política en Tucumán para las elecciones de marzo de 1941, 5 de febrero de 1941, en Fondo Agustín P. Justo, caja 103, doc. 44.

127 "Del escenario político", en La Gaceta, Tucumán, 27 de julio de 1941, Fondo Agustín P. Justo, caja 103, doc. 91 .

${ }^{128}$ La Prensa, Buenos Aires, 31 de agosto de 1942.

${ }^{129}$ Ernesto Zavalia Matienzo a Agustín Justo, Buenos Aires, 16 de octubre de 1942, en Fondo Agustín P. Justo, caja 104, doc. 321.

${ }^{130}$ Miguel Campero a Agustín Justo, Tucumán, 20 de agosto de 1942, en Fondo Agustín P. Justo, caja 124, doc. 92 .

${ }^{131}$ Miguel Campero a Agustín Justo, Tucumán, 14 de septiembre de 1942, en Fondo Agustín P. Justo, caja 124, doc. 121.

${ }^{132}$ Héctor de la Fuente a Agustín Justo, La Rioja, 1 de noviembre de 1941, en Fondo Agustín P. Justo, caja 103, doc. 220.

${ }^{133}$ Para un análisis detenido de los entretelones del conflicto, cfr. Carlos de la Torre, "El borrascoso Colegio Electoral de 1942", en La Gaceta, San Miguel de Tucumán, 3 de enero de 2016. Disponible en www.lagaceta. com.ar/nota/666730/opinion/borrascoso-colegio-electoral-1942.html [fecha de consulta: 2 de septiembre de 2017].

${ }^{134}$ Informe político sobre Tucumán, Tucumán, s/f, en Fondo Agustín P. Justo, caja 106, doc. 133. 
El gobernador Miguel Critto convocó a elecciones de cincuenta y tres electores para el 18 de octubre de $1942^{135}$. En vísperas de las elecciones el Gobernador y los principales candidatos a la gobernación resaltaron el clima de corrección en el que se había desarrollado la campaña y el grado de "cultura cívica" alcanzado por los tucumanos ${ }^{136}$. No obstante, los resultados de la elección terminaron en un empate técnico: la fórmula de los demócratas cosechó veintiséis electores con (40.877 votos) y la Alianza Radical otros veinticinco electores (unos 42.926 votos). La asimetría se debía al sistema de voto indirecto que más allá de la cantidad de sufragios repartió a los electores a favor del demócrata Adolfo Piossek ${ }^{137}$.

Pronto el PDN, a fin de destrabar eventuales conflictos que se suscitarían para determinar la mayoría de electores en un colegio compuesto por cincuenta y seis miembros (y en el que se necesitaba mayoría absoluta), optó por impugnar dos electores de la Alianza en un juzgado federal. El 12 de noviembre, en la primera sesión, los electores radicales consideraron que el único juez de los diplomas -por mandado constitucionalera el mismo cuerpo colegiado.

En los días sucesivos se desarrolló una seguidilla de reuniones, bloqueos y contraofensivas. El impasse derivó en una doble elección para presidente del cuerpo con la constitución de dos colegios electorales. El "oficial" con presencia de radicales y el "demócrata" con la asistencia de los electores del partido que optaron por trasladar su Colegio a Rosario de la Frontera ${ }^{138}$.

Los conflictos continuaron durante noviembre y diciembre. En noviembre, el gobernador Miguel Critto convocó a nuevas elecciones para reemplazar a electores cesantes al mismo tiempo que los demócratas solicitaron la intervención de la provincia al gobierno nacional. Sin embargo, el presidente Ramón Casillo resolvió "intervenir" el Colegio Electoral, nombrando comisionado al conservador puntano Alberto Arancibia Rodríguez con el objetivo de "presidir la elección", y en caso de que el Colegio no lograse la conformación, para que decretase su caducidad y llamase a nuevos comicios.

En el decreto, consideró que el procedimiento eleccionario se había "desviado de sus cauces constitucionales"139. Los demócratas, en tanto, conversaron con el concurrencismo la posibilidad sustituir al candidato Miguel Campero, por el presidente de la Corte de Justicia provincial, Juan Heller, o por otros eminentes radicales como Gregorio Aráoz Alfaro o Alberto Padilla. El gobernador tucumano, en tanto, revocó la decisión de llamar a nuevas elecciones en diciembre, lo que colocaba el asunto en manos del interventor del Colegio y en los mismos demócratas. Los conflictos continuaron ${ }^{140}$. Finalmente, Ramón Castillo en una medida implacable, prorrogó y extendió los alcances del interventor Alberto Arancibia Rodríguez y al expirar el mandato del gobernador Miguel

${ }^{135}$ Decreto provincial No 1.362, en Archivo Intermedio, Expedientes Generales, legajo 37-1942, E. 36.264.

${ }^{136}$ La Nación, Buenos Aires, 18 de octubre de 1942.

${ }^{137}$ La Nación, Buenos Aires, 29 de octubre de 1942.

${ }^{138}$ La Nación, Buenos Aires, 13 de noviembre de 1942.

${ }^{139}$ Decreto No 49.560 PEN, Buenos Aires, 26 de noviembre de 1942, en Archivo Intermedio, Expedientes Generales, legajo 46-1942, E. 49.560. Presumiblemente citado del jurista estadounidense Luther Cushing, aunque el decreto no referencia la obra.

${ }^{140}$ La Nación, Buenos Aires, 20 de enero de 1943. 
Critto el 20 de febrero, lo nombró comisionado de la provincia. Dicha medida disolvió el Colegio Electoral y postergó la definición de un nuevo Gobernador hacia adelante y con mirada puesta en la sucesión presidencial ${ }^{141}$.

En los meses siguientes, mientras los demócratas cerraron filas con la candidatura del diputado nacional Eduardo Paz; los radicales seguían postulando al exgobernador Miguel Campero, con el interés de replicar una unión de fuerzas radicales en el escenario local ${ }^{142}$. Cuando se produjo la insurrección de junio, el interventor había convocado a una nueva elección a Gobernador a realizarse los primeros días de agosto, y los radicales preparaban un gran frente popular (que incluyese a todas las agrupaciones, pero, además, a socialistas y demoprogresistas, las "fuerzas democráticas" de la provincia) en una comisión normalizadora integrada por Celedonio Gutiérrez y Nicolás Sánchez Toranzo ${ }^{143}$. La provincia, en pequeña escala, era fiel reflejo de los grandes movimientos y tendencias de la política en el ámbito nacional.

\section{LA IMPOSICIÓN DEL DESIGNIO PRESIDENCIAL: \\ Cenit y colapso del poder de Castillo}

Cuando la muerte sorprendió al expresidente Agustín P. Justo en su residencia de la calle Lacroze en enero de 1943, se encontraba de lleno en los preparativos de la campaña política para las elecciones de septiembre y era uno de los candidatos más fuertes. La muerte había sorprendido al expresidente Marcelo Alvear durante marzo de 1942 (principal líder opositor) y al presidente Roberto Ortiz (durante junio). Sin embargo, ninguno de estos fallecimientos causó tanto impacto en el escenario político como el de Agustín Justo. Su nombre ya había sido proclamado por la UCR Junta Reorganizadora de la Capital Federal, contaba ya con las adhesiones de importantes núcleos provinciales partidarios, centros cívicos, asociaciones profesionales, y un número nada desdeñable de demócratas, independientes e, incluso, de radicales (como el grupo metropolitano).

Su candidatura hubiese sido un importante desafío para los planes de Ramón Castillo. Agustín Justo, aun por fuera de los resortes de la administración, podría haber contado con un número importante de electores: provincias como Santiago del Estero, La Rioja, Tucumán eventualmente podrían haber apoyado su nombre en el Colegio. Era más dudoso el comportamiento de los electores de Santa Fe, Buenos Aires y la Capital Federal (en caso de que ganaran los radicales). Las especulaciones fueron muchas y se encuentran en el terreno de lo ficticio, pero una verdad parece inexorable: de llegar Justo a las elecciones hubiese sido un serio contrincante del candidato de Castillo; y este aún con la maquinaria del fraude aceitada -compleja, aunque efectiva- no hubiese podido arrebatar un resultado contrario a sus deseos.

\footnotetext{
${ }^{141}$ Decreto No 143.157 PEN, Buenos Aires, 16 de febrero de 1943, en Archivo Intermedio, Dirección Nacional Electoral, caja 74, Carpeta 91.

${ }^{142}$ La Nación, Buenos Aires, 21 de mayo de 1943.

${ }^{143}$ La Nación, Buenos Aires, 4 de junio de 1943.
} 
La actitud que hubiesen tenido los radicales del comité nacional sobre Agustín Justo es difícil de reexaminar, aunque está en el terreno de lo "especulable". Desde el punto de vista interno-partidario fue claro en los meses siguientes el triunfo de la posición "unionista" y el desplazamiento de los sectores intransigentes, que, aunque activos y programáticos, se vieron coartados por el núcleo metropolitano vinculado al liderazgo del expresidente Marcelo Alvear ${ }^{144}$. No es descabellado suponer que el radicalismo se hubiese podido unir en un frente "antifascista" encabezado por el General en una fórmula "extrapartidaria" como la que algunos radicales, tiempo después, ofrecieron al ministro de Guerra, Pedro Ramírez ${ }^{145}$.

El mes de febrero de 1943 fue de definiciones. En el ámbito internacional, el conflicto mundial sufriría un vuelco irreversible con la rendición de las tropas nazis en Stalingrado, que, además, debían enfrentar una gran contraofensiva aliada en el norte de África. En el ámbito doméstico, desaparecido Justo, Castillo se aprestaba a dar su apoyo a un sucesor dentro de las filas demócratas que estaba entre los tres grandes candidatos que sonaban desde meses atrás: su ministro de Justicia e Instrucción Pública, Guillermo Rothe -neutralista y cordobés-, Rodolfo Moreno -gobernador de Buenos Aires y de tendencia reformista- y Robustiano Patrón Costas - salteño y quintaesencia del conservadurismo del norte, además de presidente provisional del Senado-. En los círculos políticos, pese a la predilección natural que tenía el Presidente por su ministro Guillermo Rothe, se estimaba que la definición serían ese mes y que Ramón Castillo había "endurecido" su postura con los candidatos en el sentido de que cada agrupación debía definir sus propios nombres (esto es, el del Presidente los demócratas; y el del Vicepresidente, los antipersonalistas), en un contexto donde el cambio de orden del binomio demostraba simbólicamente el cambio de fuerzas al interior de la coalición de gobierno ${ }^{146}$.

El 18 de febrero, el nombre del próximo candidato a Presidente fue consagrado a la prensa periódica: el salteño Robustiano Patrón Costas. Luego de una serie de entrevistas en los círculos oficiales, y entre el presidente provisional del Senado con Ramón Castillo, su nombre para encabezar el binomio oficialista fue resuelto ${ }^{147}$. ¿Compromisos asumidos? ¿Devolución de favores políticos? La coalición del norte logró un triunfo pírrico.

${ }^{144}$ Cfr. Ana Virginia Persello, Historia del radicalismo, Buenos Aires, Edhasa, 2007, pp. 122-125; Luna, Alvear..., op. cit., p. 326 y ss.

${ }^{145}$ Potash, op. cit., pp. 252-262.

${ }^{146}$ Informe confidencial al Sr. Ricardo Peralta Ramos (La Razón), Buenos Aires, 17 de diciembre de 1942, en Fondo Agustín P. Justo, caja 104, doc. 442. Cabe recordar que la vicepresidencia desde la conformación de la alianza Concordancia en 1931 había estado reservada para el PDN (el conservador Julio A. Roca (h) había sido vicepresidente de Agustín Justo, y Ramón Castillo de Roberto Ortiz). Que ahora fuese el primer término para los demócratas nacionales y la vicepresidencia para los antipersonalistas, no era menor, dado que representaba esa reconfiguración de poder real que se estaba dando entre las fuerzas oficialistas.

${ }^{147}$ La Nación, Buenos Aires, 18 de febrero de 1943. 
Figura 2

El presidente Ramón Castillo, ministros (de izq. a derecha: Almte. Mario Fincati, Enrique Ruiz Guiñazú, Gral. Pedro P. Ramírez), el senador Robustiano Patrón Costas y el cardenal Santiago Copello, ante un desfile militar (s/f)

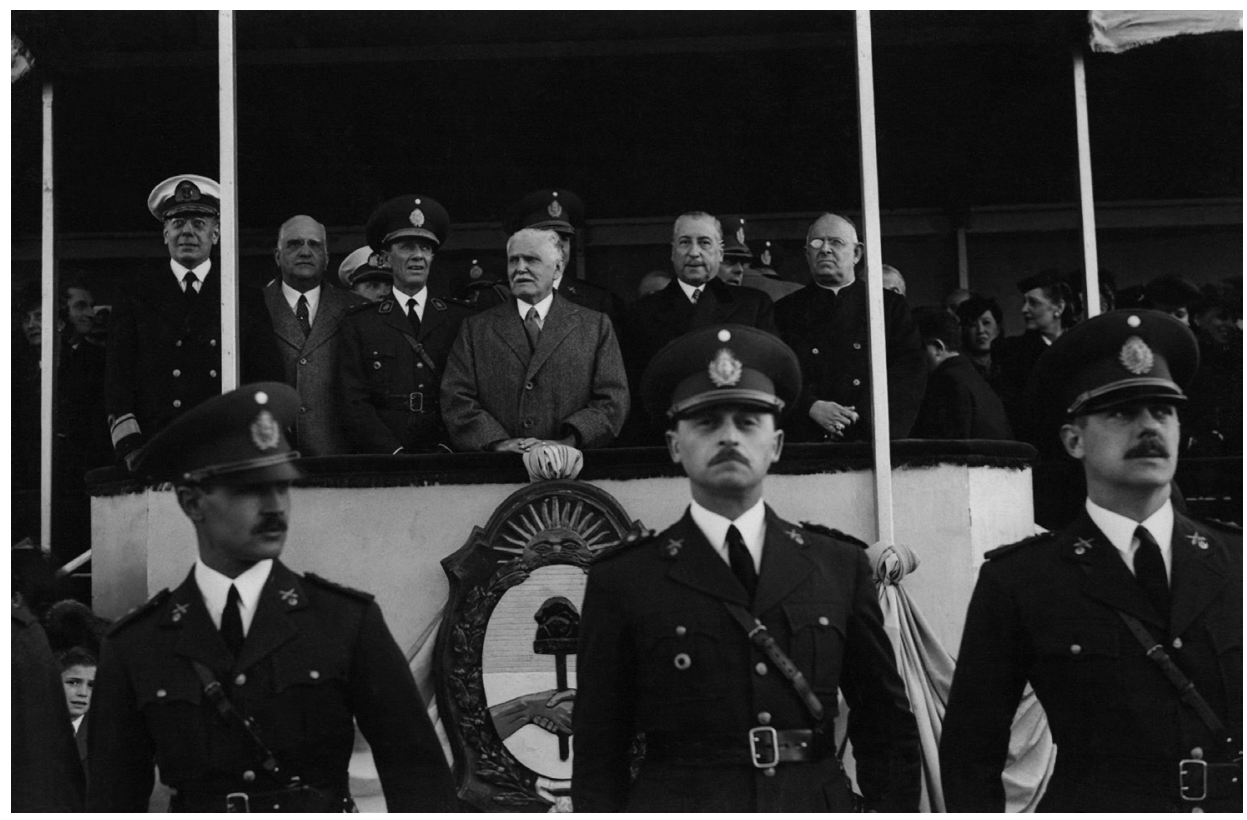

Cortesía del Archivo General de la Nación (Buenos Aires), Departamento de Documentos Fotográficos.

Sin embargo, las primeras señales de rebeldía surgieron en la provincia de Buenos Aires. El Partido Demócrata bonaerense, señaló rápidamente muestras de inconformidad ante el modus operandi del Poder Ejecutivo Nacional y con la elección de Ramón Castillo. El sector bonaerense solicitó un mayor "entendimiento" sobre el programa que sostendría el oficialismo en materia de "política interna e internacional", negándose a discutir sobre nombres ni candidaturas sin resolver aspectos programáticos primero ${ }^{148}$. Una misiva del diputado nacional por Buenos Aires, Justo Rocha, al presidente del PDN, el senador Gilberto Suárez Lago, criticaba no solo la política internacional del presidente Ramón Castillo sino algunos lineamientos de política interna, como el estado de sitio que vivía Argentina desde los ataques de Pearl Harbor ${ }^{149}$.

En los días sucesivos, impuesta la candidatura de Robustiano Patrón Costas y virtualmente descartada la del gobernador Rodolfo Moreno, este intentó algunos movimientos de contraofensiva. En diversos conciliábulos con los senadores Alberto Barceló y Antonio Santamarina insistió en la necesidad de adoptar un "programa" definido sobre

148 "La cuestión presidencial", en La Nación, Buenos Aires, 17 de febrero de 1943.

${ }^{149}$ Carta de Justo Rocha a Gilberto Suárez Lago (PDN), La Plata, 2 de febrero de 1943, en Fondo Agustín P. Justo, caja 134, doc. 309. 
los diversos ejes de temas que tendría que afrontar la próxima presidencial. A fines de febrero, los diputados bonaerenses en el Congreso Nacional se reunieron con el objetivo de emitir una resolución que contemplase un programa y plataforma para la próxima campaña presidencial ${ }^{150}$.

La "rebelión demócrata" fue tomando carácter intransigente en las semanas sucesivas, fue descartada a principios de abril. El poder presidencial se impuso ante cualquier tipo de rebeldía provincial. Ramón Castillo dio un ultimátum al gobernador Rodolfo Moreno -renuncia o intervención federal- por lo que este y sus principales ministros optaron por presentar su dimisión e inclinarse ante la autoridad federal. Asimismo,consideró que su renuncia al cargo se debía ante la "imposibilidad" de continuar el cumplimento de su programa "en armonía con quienes habían sido los factores de su candidatura y el apoyo principal del gobierno"151. La asamblea bonaerense aceptó días después la renuncia ${ }^{152}$.

Doblegado el poder bonaerense en abril, Ramón Castillo buscó imponerse una vez más en los primeros días de junio. Esta vez fue con su ministro de Guerra con pretensiones presidenciales: el general Pedro Ramírez. Este venía negociando con un grupo de radicales una eventual fórmula extrapartidaria de cara a las elecciones de septiembre ${ }^{153}$. Sin embargo, la directriz presidencial resultó contraproducente, y si había sido efectiva en el universo político-partidario, fue inocua con el General conspirativo y con la corporación militar que se mostró más renuente y desleal de lo que aparentaba. Los sucesos del 3 y 4 de junio de 1943 son bien conocidos: deslealtades, traiciones e incertidumbres rodearon al evento ${ }^{154}$.

Por tanto, las causalidades próximas del golpe hay que buscarlas en el accionar propio del presidente Ramón Castillo y en el de sus aliados militares en los últimos días de mayo e inicios de junio. Una cadena de errores, desaciertos y falsos planes de contraofensiva fracasaron y los acontecimientos inclinaron la balanza hacia un bando más articulado y más efectivo "operativamente" de la institución militar. Luego, los problemas de la legitimidad, claro está, cayeron como un muro de argumentos sobre los hombros de la institución presidencial, sus acuerdos y sus aliados.

\section{ConClusiones}

Este artículo intentó explorar algunas conjeturas sobre la política presidencial de Ramón Castillo a inicios de la década de 1940 y buscó presentar algunas contribuciones origi-

\footnotetext{
${ }^{150}$ La Nación, Buenos Aires, 23 de febrero de 1943.

${ }^{151}$ La Nación, Buenos Aires, 14 de abril de 1943.

${ }^{152}$ La Nación, Buenos Aires, 17 de abril de 1943.

${ }^{153}$ Potash, op. cit., pp. 266-288.
}

${ }^{154}$ Devoto, "Para una reflexión...", op. cit., pp. 171-186. Sobre los sucesos desde los protagonistas, cfr. Domingo Martínez, "Historia de los acontecimientos del día 4 de junio de 1943 vividos por el Jefe de Policía de la Capital Federal, general de Brigada D. Domingo Martínez" (manuscrito), en Archivo Robustiano Patrón Costas, correspondencia (personal del autor); también Martín Aberg Cobo, "La Revolución de 1943" en Horacio Zorraquín Becú, Enrique Ruiz Guiñazú (h), Martín Aberg Cobo y Adolfo Vicchi, Cuatro revoluciones argentinas (1890-1930-1943-1955), Buenos Aires, Ediciones del Club Nicolás Avellaneda, 1960, pp. 80-81. 
nales sobre las redes partidarias y políticas en el último periodo del gobierno conservador. Primero, ha descrito cómo la sucesión presidencial dirigida convirtió los acuerdos fraudulentos de la década conservadora en más visibles e ilegítimos ante la opinión pública y el resto de los partidos políticos, acelerando los debates sobre la viabilidad del gobierno restaurado. La reconfiguración del tablero político, debido a la desaparición de líderes que garantizaban el sostenimiento de esa particular democracia -ya sea con cuotas de popularidad o por su habilidad de gestar acuerdos entre dirigentes y actores cruciales, fue central para el específico desenlace y el advenimiento del golpe militar. Sin embargo, este no fue un resultado inevitable del impasse político de la década de 1940, sino, más bien, "posible" dentro del repertorio de soluciones a la crisis de legitimidad y acelerado por la misma política conducida desde la institución presidencial.

En segundo lugar, el artículo buscó reconsiderar las capacidades políticas del presidente Ramón S. Castillo. En términos generales, la historiografía argentina ha tendido a verlo o como un gobernante reaccionario frente a las políticas reformistas de su sucesor Roberto Ortiz, o como un Presidente debilitado frente a los sectores nacionalistas de las Fuerzas Armadas que le arrebataron el poder. En este sentido, el artículo procuró, primero, vincularlo con el universo sáenzpeñista y conservador y complejizar su visión de la política en el largo plazo; pero, además, se orientó a enfatizar los intentos del último Presidente demócrata por reconstruir el tejido político-partidario en algunos casos provinciales. Particularmente el escrito analizó cómo las intervenciones en las provincias de Jujuy, Corrientes y Tucumán fueron escenarios en los que el Presidente, y las fuerzas conservadoras, recuperaron cuotas de poder en escala local. Estos intentos fueron casos ejemplificadores de una política general de concentración de poder y consolidación de bases (aparentemente) sólidas, que involucraron la negociación con otros actores del sistema político como el poder militar.

Sin duda, los esfuerzos de voluntad del Presidente, sus habilidades políticas y la reconstitución del tejido político-partidario al interior del oficialismo, no fueron elementos suficientes para garantizar su supervivencia en el poder, frente a un actor más poderoso, como el militar. Sin embargo, parte de la explicación a ese particular desenlace debe buscarse en la misma política que promovió el Poder Ejecutivo, sus acciones, y sus inesperadas consecuencias, en un gran cuadro de reducidas expectativas que rodeaban a su autoridad. 